\title{
WestVirginiaUniversity
}

THE RESEARCH REPOSITORY @ WVU

Graduate Theses, Dissertations, and Problem Reports

2008

\section{Toward the synthesis of polycyclic aromatic compounds as nano- carbon cages}

Ruoxin Zhang

West Virginia University

Follow this and additional works at: https://researchrepository.wvu.edu/etd

\section{Recommended Citation}

Zhang, Ruoxin, "Toward the synthesis of polycyclic aromatic compounds as nano-carbon cages" (2008). Graduate Theses, Dissertations, and Problem Reports. 4434.

https://researchrepository.wvu.edu/etd/4434

This Thesis is protected by copyright and/or related rights. It has been brought to you by the The Research Repository @ WVU with permission from the rights-holder(s). You are free to use this Thesis in any way that is permitted by the copyright and related rights legislation that applies to your use. For other uses you must obtain permission from the rights-holder(s) directly, unless additional rights are indicated by a Creative Commons license in the record and/ or on the work itself. This Thesis has been accepted for inclusion in WVU Graduate Theses, Dissertations, and Problem Reports collection by an authorized administrator of The Research Repository @ WVU. For more information, please contact researchrepository@mail.wvu.edu. 
Toward the Synthesis of Polycyclic Aromatic Compounds as Nano-carbon Cages

\title{
Ruoxin Zhang
}

\author{
Thesis \\ Submitted to the Eberly College of Arts and Sciences \\ at \\ West Virginia University \\ In partial fulfillment of the requirements for the degree of \\ Master of Science \\ in Organic Chemistry
}

Kung K. Wang, Ph. D., Advisor

George A. O’Doherty, Ph. D.

Xiaodong M. Shi, Ph. D.

C. Eugene Bennett Department of Chemistry

Morgantown, West Virginia

2008

Keywords: Polycyclic aromatic compound, Diels-Alder reaction 


\section{ABSTRACT \\ Toward the Synthesis of Polycyclic Aromatic Compounds as Nano-carbon Cages}

\section{Ruoxin Zhang}

Under mild conditions, a key intermediate, diketone 51, for synthesis of buckybaskets was successfully synthesized through methylation of diketone 52. The Diels-Alder reaction between 2,5-dicarbomethoxy-3,4diphenylcyclopentadienone (57) and 5,6-dimethoxy-2-norbornene (58) provided diester 56. Decarbonylation of 56 furnished diester 55, which on hydrolysis afforded diacid 54. Intramolecular acylation of diacid $\mathbf{5 4}$ furnished diketone $\mathbf{5 2}$. 


\section{Dedicated to}

my husband and my parents 


\section{ACNOWLEDGEMENTS}

First, I would like to thank my advisor Dr. Kung K. Wang, for his patience, constant encouragement and constant guidance throughout my graduate studies. His mentorship was essential to the completion of this thesis.

I also especially thank my research committee members, Dr. George A. O’Doherty and Dr. Xiaodong M. Shi for their help and assistance.

My special thanks go to Dr. Jeffery Peterson and Dr. Novruz Akhmedov's work really helped me to determine structures of my products.

My very special appreciation goes to Lily Wang for her help, suggestions and discussions.

I would also like to thanks the former and present group members, Dr. Weixiang Dai, Dr. Hua Yang, Lily Wang, Daehwan Kim, Hu Cui, Bo Wen and Elbin Parbin for their help and support.

Special appreciation and gratitude are due to my husband and my parents for their constant support and love.

Financial support from the C. Eugene Bennett Department of Chemistry at West Virginia University and the National Science Foundation are gratefully acknowledged. 


\section{TABLE OF CONTENTS}

Title Page

i

Abstract

ii

Dedications

iii

Acknowledgements iv

Table of Contents

$\mathrm{V}$

Experimental Section

vi

List of Figures

Vii

Part I

Toward the Synthesis of Polycyclic Aromatic Compounds as

Nano-carbon Cages

1. Introduction

2. Research Objects

3. Literature Survey 5

$\begin{array}{ll}\text { 4. Result and Discussion } & 10\end{array}$

5. Conclusions 16 


\section{Part II}

\section{Experimental Section}

General Methods and Materials 18-23

$\begin{array}{ll}\text { References } & 23-26\end{array}$

$\begin{array}{ll}\text { Appendix } & 27\end{array}$

${ }^{1}$ H NMR spectra for Exo-cis-5,6-dimethoxy-2-Norbornene 5728

${ }^{13} \mathrm{C}$ NMR spectra for Exo-cis-5,6-dimethoxy-2-Norbornene 57

${ }^{1} \mathrm{H}$ NMR spectra for Diels-Alder Adduct 56

${ }^{13} \mathrm{C}$ NMR spectra for Diels-Alder Adduct 56

${ }^{1} \mathrm{H}$ NMR spectra for Diester $\mathbf{5 5} 32-33$

${ }^{13} \mathrm{C}$ NMR spectra for Diester $\mathbf{5 5} 34$

${ }^{1} \mathrm{H}$ NMR spectra for Diacid $\mathbf{5 4} 35$

${ }^{13} \mathrm{C}$ NMR spectra for Diacid $\mathbf{5 4} 36$

${ }^{1} \mathrm{H}$ NMR spectra for Diketone $\mathbf{5 2} 37$

${ }^{13} \mathrm{C}$ NMR spectra for Diketone $\mathbf{5 2} 38$

${ }^{1} \mathrm{H}$ NMR spectra for Diketone $\mathbf{5 1} 39$

${ }^{13} \mathrm{C}$ NMR spectra for Diketone $\mathbf{5 1} 40$

IR spectra for Diels-Alder Adduct 56

IR spectra for Diester $\mathbf{5 5} 42$

IR spectra for Diacid $\mathbf{5 4} 43$

IR spectra for Diketone 52

IR spectra for Diketone 51 45 


\section{LIST OF FIGURES}

Figure 1. Representative Examples of Buckybowls 2

Figure 2. Structure of Ru-corannulene Complex 3

Figure 3. Structure of Exo- and Endo-corannulene Metal Complex 4

Figure 4: ORRTEP Drawing of the Crystal structures of $\mathbf{5 6} \quad 14$

Figure 5: nOe of diketone $52 \quad 15$

Figure 6: nOe of diketone 51 16 


\section{Part I}

\section{Toward the Synthesis of Polycyclic Aromatic Compounds as}

\section{Nano-carbon Cages}

\section{Introduction}

In 1985 , the first buckyball composed of 60 carbon atoms, $\mathrm{C}_{60}$, was discovered by H. W. Kronto (University of Sussex, UK), R. F. Curl and R.E. Smalley (both from Rice University, USA). ${ }^{1}$ This uniquely structured molecule was named "buckminsterfullerene", from an architect Buckminster Fuller, who conceived of geodesic dome to resemble the hollow and extremely stable molecule. Since then buckminsterfullerene and other higher fullerenes have attracted a considerable attention for the exploration of their chemical reactivates and physical properties. ${ }^{2}$ New synthesis approaches to these molecules have also been explored. Until now, chemists use gas phase chemistry to replicate the environment of interstellar space to produce buckyballs. Unfortunately, the reaction happens at high temperatures which make the reaction hard to control and only affords very small amount of products. It is still a challenge for chemists to finding a way to synthesize buckyballs. One of the most prevalent synthetic strategies to meet the challenge is to develop a practical method of producing fragments having the curved carbon frameworks represented on the surface of buckyball. Subsequent assembly of these fragments could then lead to buckyballs. 
Interestingly, if a buckyball is taken apart, the piece wouldn't be stable because it would have dangling bonds, but if hydrogen atoms are put on the dangling bonds, the structure is stabilized. This bowl shaped molecule is called buckybowl or buckybasket. ${ }^{2,5}$ The first synthesis of the smallest buckybowl corannulene $\left(\mathrm{C}_{20} \mathrm{H}_{10}, \mathbf{1}\right)$, was reported by Barth and Lawton in $1966 .{ }^{3,4,5 b}$ Corannulene is the minimal structural subunit on the surface of $\mathrm{C}_{60}$ that processes a curvature. Later several other examples of buckybowls, such as, semibuckminsterfullerene $\left(\mathrm{C}_{30} \mathrm{H}_{12}, \quad 2\right),{ }^{5 \mathrm{c}, 6}$ dibenzo[a,g]corannulene $\quad\left(\mathrm{C}_{28} \mathrm{H}_{14}, \quad 3\right)^{5 \mathrm{a}, 5 \mathrm{~b}, 7 \mathrm{a}, 7 \mathrm{~b}} \quad$ and tribenzo[a,d,j]corannulene $\left(\mathrm{C}_{32} \mathrm{H}_{16}, 4\right),{ }^{5 \mathrm{a}, 7 \mathrm{c}, 7 \mathrm{~d}}$ were synthesized and characterized.
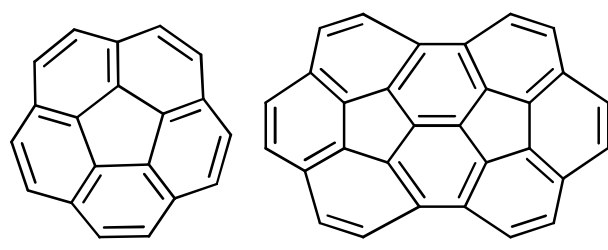

$\mathrm{C}_{20} \mathrm{H}_{10}, 1$

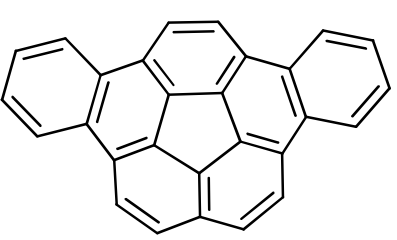

$\mathrm{C}_{28} \mathrm{H}_{14}, 3$

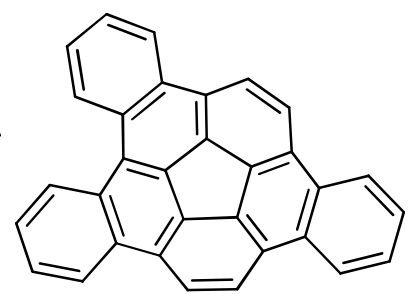

$\mathrm{C}_{32} \mathrm{H}_{16}, 4$

Figure 1. Representative Examples of Buckybowls

The hydrogen atoms on the edge or rim of the carbon atoms of buckybowls could be used for coordination, and the bowl shape also provide enough space for binding metal ions. Therefore, much effort has been directed toward the synthesis of metal complexes of buckminsterfullerene which may ultimately allow the preparation of 
endohedral metal complexes of $\mathrm{C}_{60}$. In, 1997, Seiders et al. reported the first transition metal complex of corannulene $\mathbf{5}$ and the first example of $\eta^{6}$-coordination to a curved polynuclear aromatic hydrocarbon (PAH) surface. ${ }^{8}$ After that, more corannulene transition-metal complexes have been reported, such as Fe-corannulene complex, Ni-corannulene complex and Pt-corannulene complex. ${ }^{9}$ In 2004 , Vecchi et al. characterized the first corannulene complex with two $\eta^{6}$-coordinated $\{\mathrm{Cp} * \mathrm{Ru}\}$ units 6 which bind to non-adjacent arene rings on opposite sides of corannulene. ${ }^{10}$

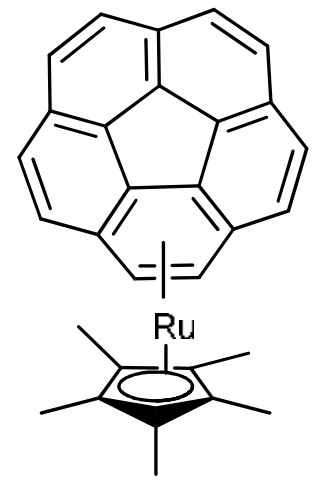

5

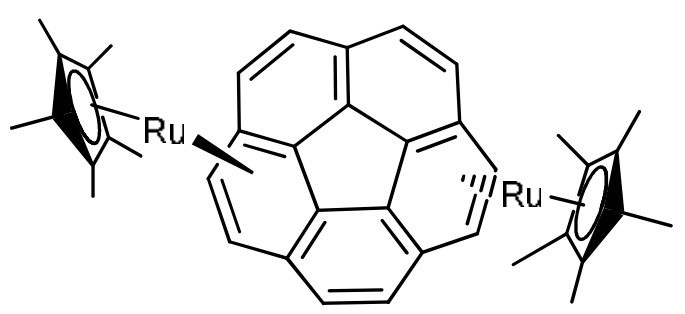

6

Figure 2. Structure of Ru-corannulene Complex

Due to the intrinsic curvature, the buckybowl has two curved surfaces, convex (or exo) and concave (or endo). The metal ion intereations with surfaces are much more complicated because of two sides and different sites on each side where the metal ions can attach. ${ }^{11}$ Many studies show a preference for exo-metal binding. It is worth noting that exo-metal binding can assist the activation of the surface carbon atoms and make them more accessible to further reactions. ${ }^{8}$ 


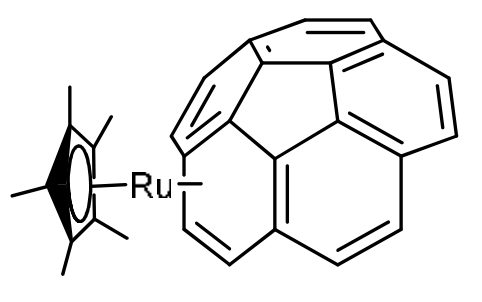

exo-complex, 7

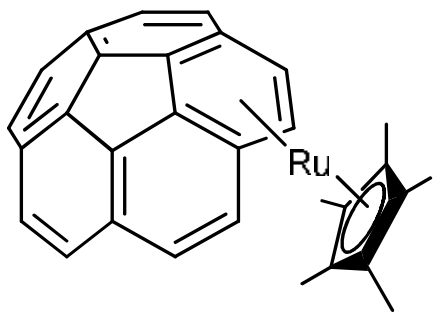

endo-complex, 8

Figure 3. Structure of Exo- and Endo-corannulene Metal Complex

Similarly, buckybowls can also be synthesized through flash vacuum pyrolysis (FVP) method, which require high temperatures and the yields are low. ${ }^{2,5}$ Our interests are focused on the synthesis of curved polycyclic aromatic hydrocarbons using solution-phase chemical reactions.

\section{Research Objective}

Based on our previous research on the synthesis of polycyclic aromatic hydrocarbons involving condensation of benzannulated enediynes and aryldiketones to produce benzannulated enediynyl propargylic diols for subsequent reduction and a sequence of cascade cyclization reactions, ${ }^{12}$ we believe that a variety of other curved polycylic aromatic hydrocarbons could also be synthesized by using different diketones with benzannulated enediynes. 


\section{Literature Survey}

In 2001, Dr. Hongbin Li in our group reported the use of thionyl chloride to induce an $\mathrm{S}_{\mathrm{N}} \mathrm{i}$ ' reaction of the benzannulated enediynyl propargylic alcohol (Scheme 1). ${ }^{12 \mathrm{~d}}$ The alcohol 12 was obtained from condensation of 9-fluorenone (10) with the lithium acetylide 11, obtained by lithiation of 1-(2-ethynylphenyl)-2-phenylethyne with n-butyllithium followed by hydrolytic workup. Treatment of $\mathbf{1 2}$ with thionyl chloride promoted a sequence of reactions with an initial formation of the cholorosulfite 13 followed by an $\mathrm{S}_{\mathrm{N}} \mathrm{i}$ ' reaction ${ }^{13}$ to produce in situ the chlorinated benzoenyne-allene 14. A Schmittel cyclization reaction then generated the biradical 15, which in turn underwent a radical-radical coupling to afford the formal Diels-Alder adduct $\mathbf{1 6}$ and, after tautomerization, gave chloride 17 . The chloride 17 was prone to hydrolysis and, on exposure to water/silica gel, afforded 18 in 74\% yield.<smiles>O=C1c2ccccc2-c2ccccc21</smiles>

10

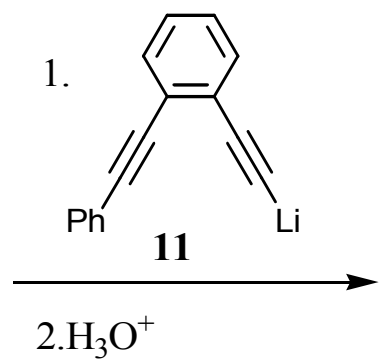

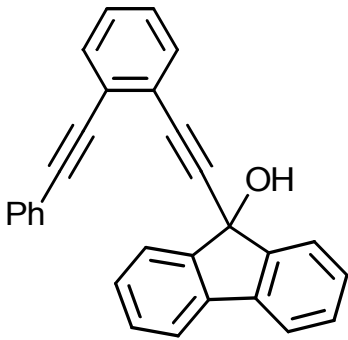

12
$\mathrm{SOCl}_{2}$

pyridine

$0^{\circ} \mathrm{C}$ to rt

$4 \mathrm{~h}$ 

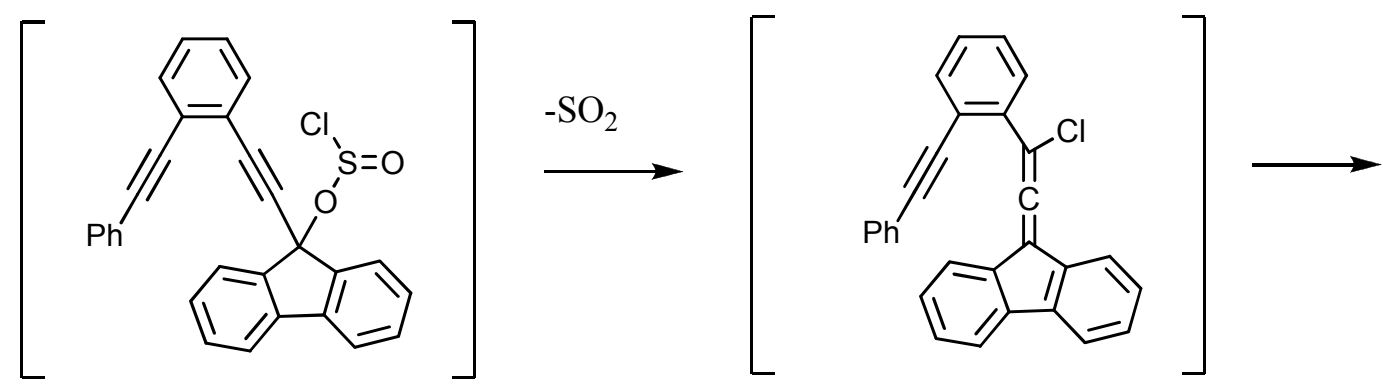

13

14

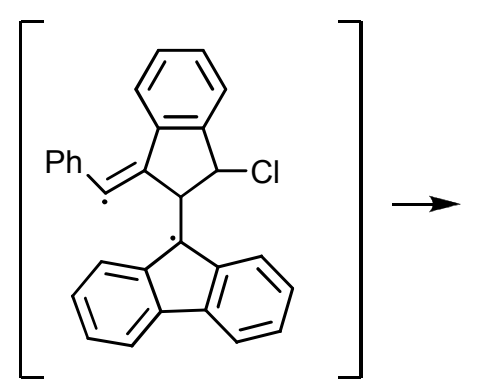

15
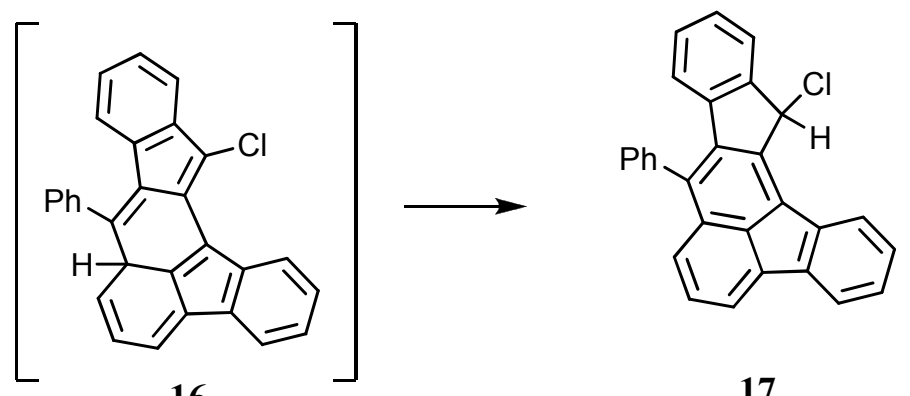

16

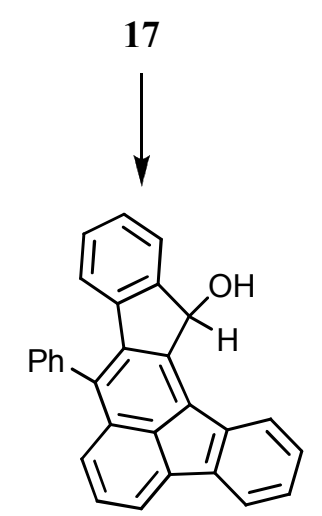

$18,74 \%$

Scheme 1 Thionyl Chloride Induced Cascade Cyclization Reactions

In 2003, Dr. Yonghong Yang studied the use of molecules have two benzannulated enyne-allene units for the synthesis of polycyclic aromatic compounds. ${ }^{14}$ The intermediate diketone 21 was synthesized by treatment of diester 19 with 4-octyne to form $\mathbf{2 0}$ followed by two intramolecular acylation reactions. The diol $\mathbf{2 2}$ was synthesized form condensation between diketone 21 and 2 equivalents of lithium acetylide 11. It was 
assumed that the Schimttel cyclization reaction of $\mathbf{2 2}$ would produce the desired hydrocarbon 24. Unexpectedly, cleavage of the central benzene ring occurred during the course of cyclization, leading to highly twisted 1,1'-dialkyl-9,9'-bifluorenylidenes $\mathbf{2 3}$. It is worth noting that hydrocarbon 24 has a 52-carbon framework represented on the surface of $\mathrm{C}_{60}$.<smiles>COC(=O)C1=C(c2ccccc2)C(c2ccccc2)=C(C(=O)OC)C1=O</smiles>

19

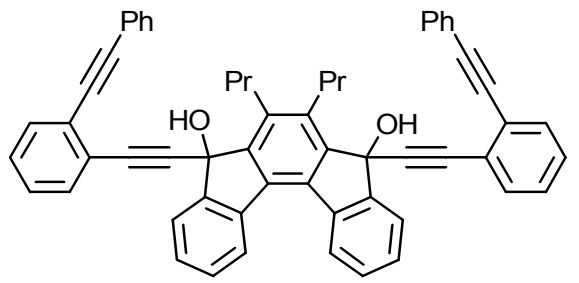

22

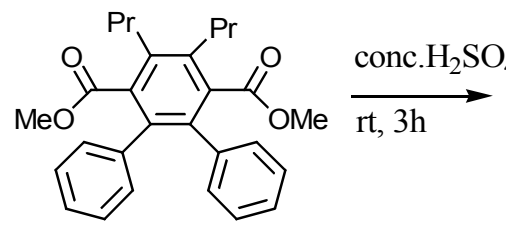

20

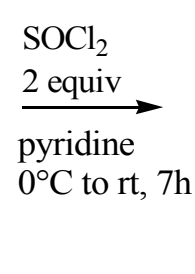

$\underset{\text { pyridine }}{\stackrel{2 \text { equiv }}{\longrightarrow}}$ $0^{\circ} \mathrm{C}$ to $\mathrm{rt}, 7 \mathrm{~h}$<smiles>CCCc1c(CC)c2c(=O)c3ccccc3c2c2c1c(=O)c1ccccc12</smiles>

21

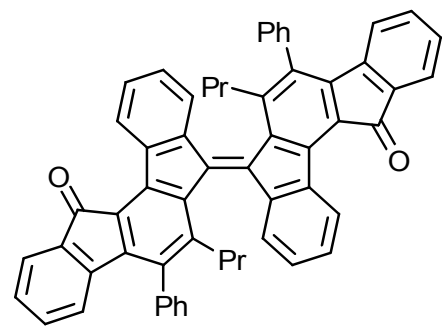

23, $5 \%$

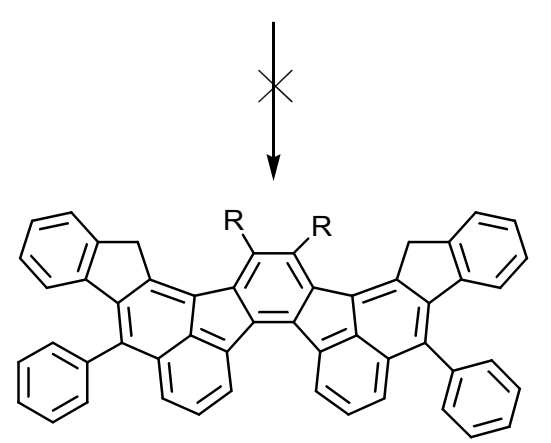

24

Scheme 2 Thionyl Chloride Induced Cascade Radical Cyclization of Benzannulated Enyne-Allenes

In 2004, Xiaoqing Han and Dr. Yanzhong Zhang reported the synthesis of $4 H$-cyclopenta[def]phenanthren-4-ones. Condensation of 1,3- 
indandiones 25, 26 with lithium acetylide 27, 28 gave diols 29-31. ${ }^{15}$ Treatment of propargylic diols 29-31 with thionyl chloride promoted a cascade sequence of reactions leading to dichlorides 34-36. Reduction of 34-36 with tributyltin hydride generated the diindeno-fused 4H-cyclopenta[ $[d e f]$ phenanthrenes 37-39. Hydrolysis of $\mathbf{3 7}$ and $\mathbf{3 8}$ furnished 40 and 41, respectively. Air oxidation of an alkaline solution of dichloride 35 produced diketone 42. It is worth noting that the diindeno-fused $4 H$-cyclopenta[def]phenanthrenes have a 41-carbon framework, 38 carbons on the aromatic rings and three carbons on the three five-membered rings, that is represented on the surface of $\mathrm{C}_{60}$.

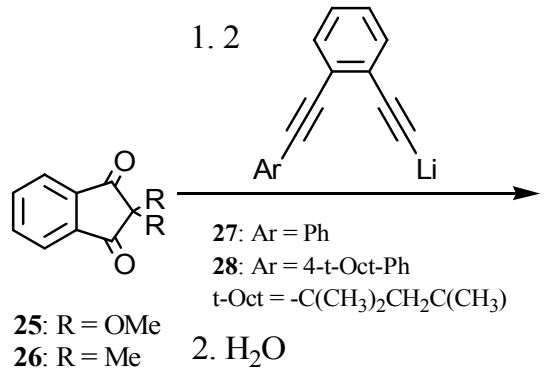

26: $\mathrm{R}=\mathrm{Me} \quad 2 . \mathrm{H}_{2} \mathrm{O}$

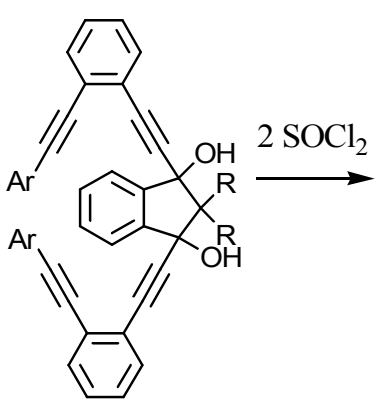

29: $\mathrm{R}=\mathrm{OMe}, \mathrm{Ar}=\mathrm{Ph}$ 30: $\mathrm{R}=\mathrm{OMe}, \mathrm{Ar}=4$-t-Oct-Ph 31: $\mathrm{R}=\mathrm{Me}, \mathrm{Ar}=\mathrm{Ph}$

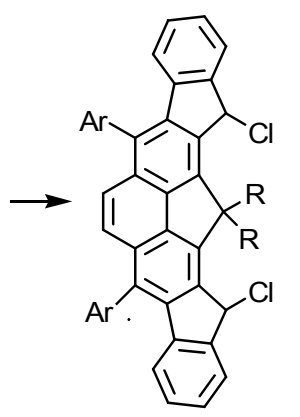

34: $\mathrm{R}=\mathrm{OMe}, \mathrm{Ar}=\mathrm{Ph}$ 35: $\mathrm{R}=\mathrm{OMe}, \mathrm{Ar}=4$-t-Oct-Ph 36: $\mathrm{R}=\mathrm{Me}, \mathrm{Ar}=\mathrm{Ph}$

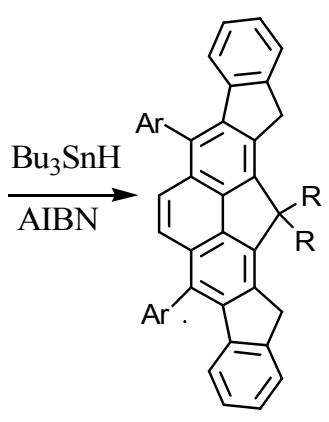

37: $\mathrm{R}=\mathrm{OMe}, \mathrm{Ar}=\mathrm{Ph}$ 38: $\mathrm{R}=\mathrm{OMe}, \mathrm{Ar}=4$-t-Oct-Ph 39: $\mathrm{R}=\mathrm{Me}, \mathrm{Ar}=\mathrm{Ph}$

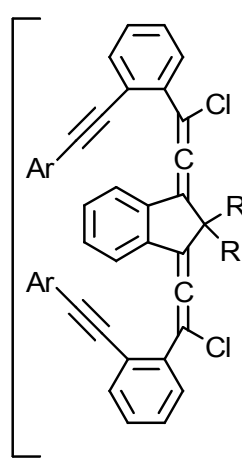

32

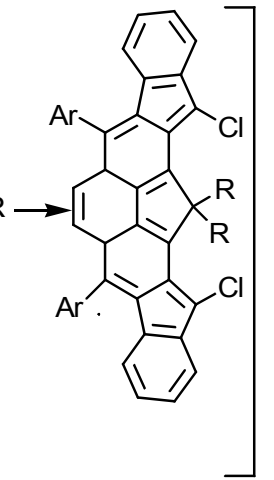

33

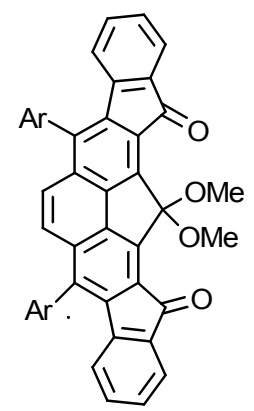

42: $\mathrm{Ar}=4-\mathrm{t}-\mathrm{Oct}-\mathrm{Ph}$ 
Scheme 3 Synthesis of Diindeno-Fused

$4 H$-cyclopenta[def]phenanthrenes

In 2006, Dr. Hua Yang studied the cyclization of diol with two benzannulated enyne-allene units induced by the thionyl chloride. ${ }^{16}$ Several methods were tried to synthesize a suitable key intermediate diketone. Finally, the diester $\mathbf{4 3}$ was obtained from the Diels-Alder reaction between diester $\mathbf{1 9}$ and 2,5-dihydrofuran, followed by decarbonylation to give 44. Intromolecular acylation followed by methylation afforded the desired diketone 46. Condensation between 46 and 2.6 equivalents of lithium acetylide $\mathbf{1 1}$ provided the benzannulated enediynyl propagylic diol 47. Treatment of diol 47 with thionyl chloride followed by silica gel chromatography directly led to diketone $\mathbf{4 8}$. The diketone $\mathbf{4 8}$ has a 54-carbon framework represented on the surface of $\mathrm{C}_{60}$ and may eventually lead to the formation of bowl-shaped polycyclic aromatic hydrocarbons (buckybowls). However, attempts to open the furan ring with trimethysilyl iodide and other methods were unsuccessful. 


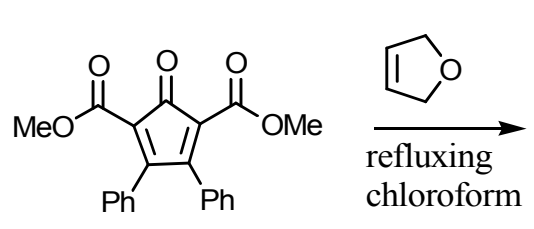

19

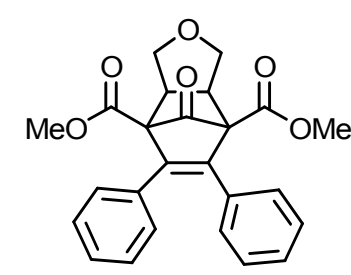

43

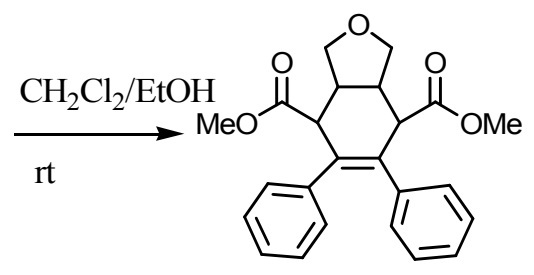

44
2. $\mathrm{SOCl}_{2}$

3. $\mathrm{AlCl}_{3}, \mathrm{CH}_{2} \mathrm{Cl}_{2}$

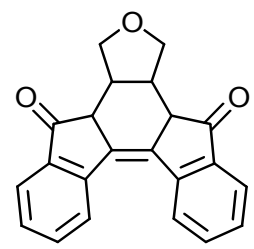

45

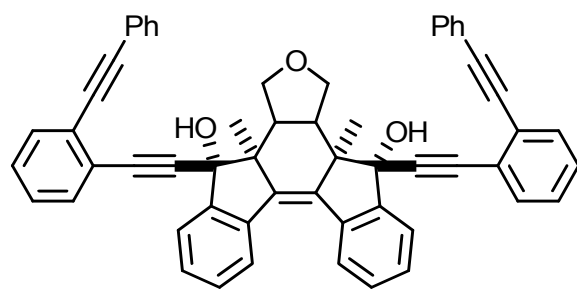

47

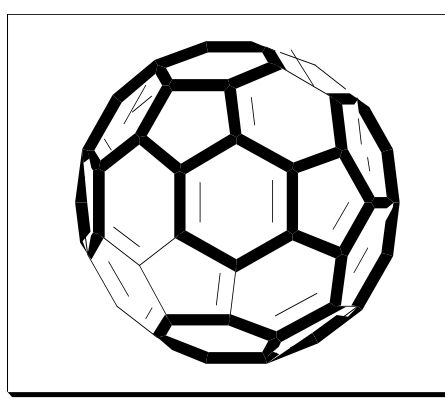

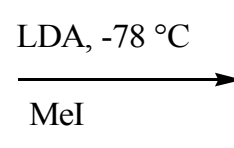

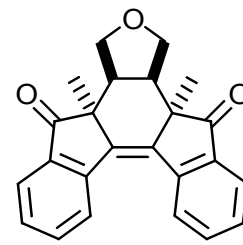

46
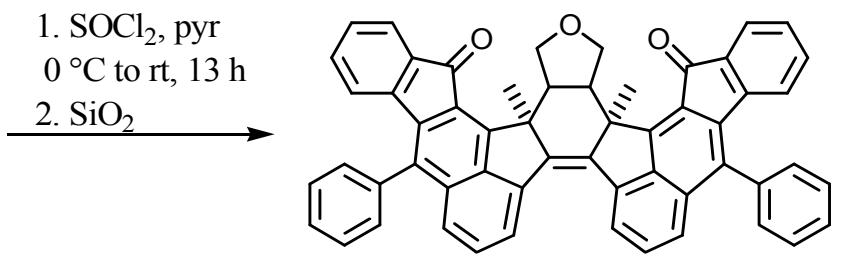

48, $57 \%$

Scheme 4 


\section{Results and Discussion}

With our ongoing interest in the synthesis of polycyclic aromatic hydrocarbons, we envisioned a retrosynthetic sequence outlined in Scheme 5 for the synthesis of polycyclic aromatic hydrocarbon 49. It was anticipated that unlike diketone $\mathbf{4 8}$ with furan ring folded inside the two benzofluorenone units preventing it from cleavage by trimethysilyl iodide. The two methoxyl groups in diketone 49 could be easily demethylated to form the corresponding diol. The diol then could be oxidatively cleaved for subsequent intramolecular connections with the carbon atoms of the two ketone groups.

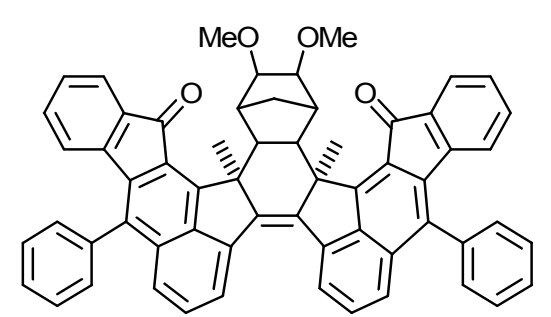

49
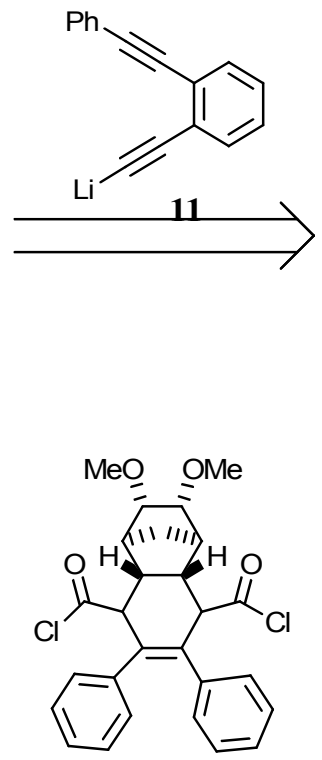

53
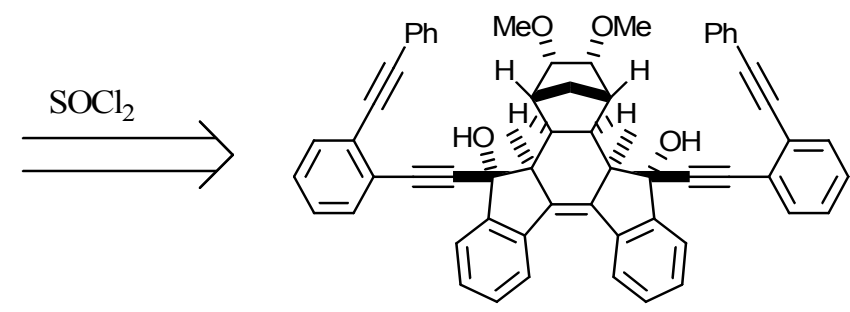

50

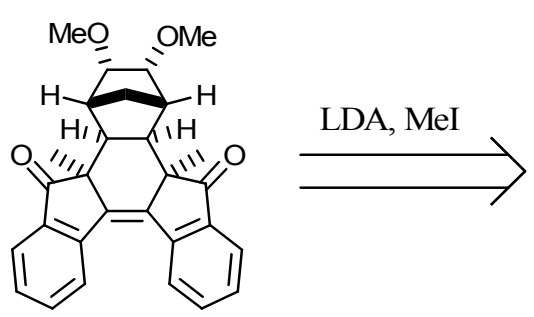

51

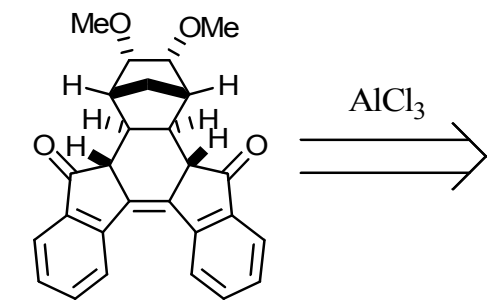

52
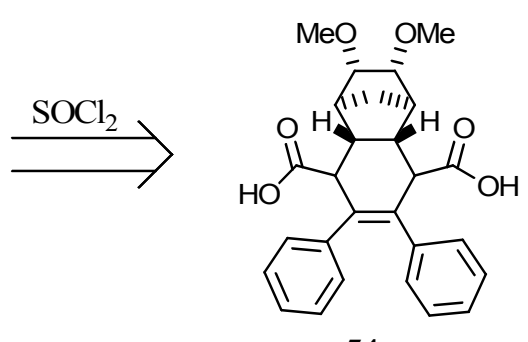

54

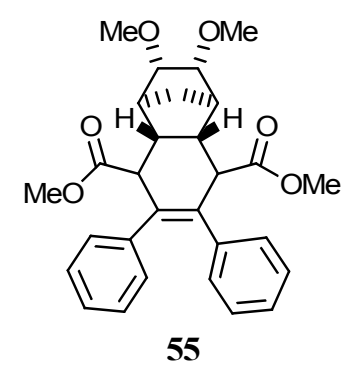




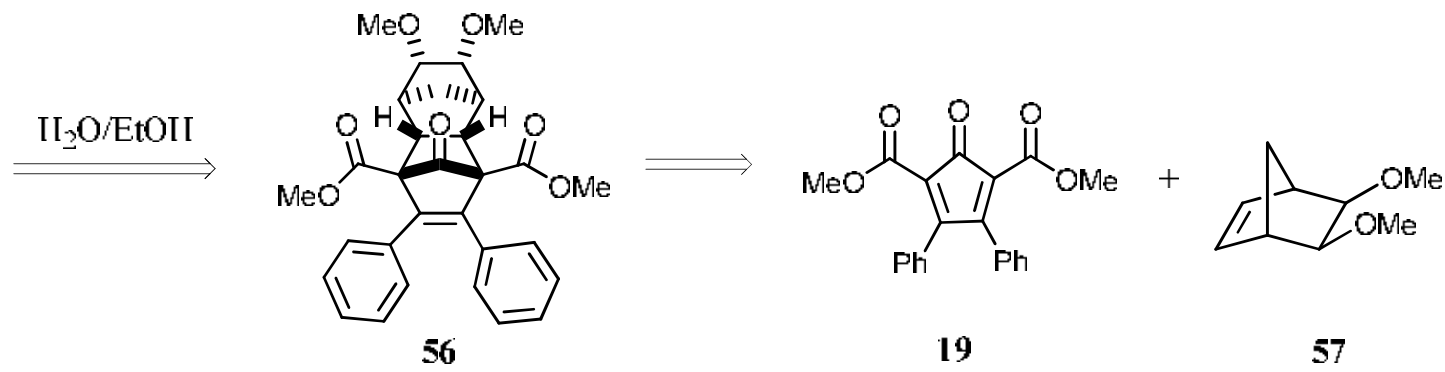

Scheme 5: Retrosynthetic analysis

The polycyclic aromatic hydrocarbon 49 could be synthesized by condensation of diketone $\mathbf{5 1}$ with lithium acetylide $\mathbf{1 1}$ followed by cascade cyclizations. The diketone $\mathbf{5 1}$ could be obtained from methylation of diketone 52. The diketone $\mathbf{5 2}$ could be produced from intramolecular acylation of diacid 54, which could be obtained from diester $\mathbf{5 5}$ followed by hydrolysis. The diester $\mathbf{5 5}$ could be obtained by decarbonylation of diester 56. The diester 56 could be synthesized through the Diels-Alder reaction between diester 19 and dimethoxy norbornene 57. The precursor 57 could be obtained through methylation of diol 58, which was prepared from oxidation of norbornadiene $\mathbf{5 9}$.

As outlined in Scheme 6, the precursor diol $\mathbf{5 8}$ was obtained through oxidation of norbornadiene as reported previously. The dimethoxy norbornene $\mathbf{5 7}$ was synthesized from diol $\mathbf{5 8}$ by deprotonation using sodium hydride in N,N-dimethylformamide followed by methylation with iodomethane to produce 57 in $39 \%$ yield. ${ }^{17}$ The Diels-Alder reaction between 2,5-dicarbomethoxy-3,4-diphenylcyclopentadienone (19) ${ }^{18}$ and dimethoxy norbornene 57 provided diester $\mathbf{5 6}$ in $82 \%$ yield, with the endo-cycloadduct as the major product and the exo-cycloadduct as the 
minor product in a 3:1 ratio. The structure of the endo-cycloadduct was confirmed by X-ray structure analysis (Figure 4). The X-ray structure of the endo-cycloadduct shows that the two carboxylate groups and the methylene bridge of the norboryl ring are on the same side of the cyclohexene ring. Dissolving diester 56 in a small amount of methylene chloride followed by decarbonylation in a mixed solvent of water and ethanol at $50^{\circ} \mathrm{C}$ for 15 hours afforded diester 55 in $63 \%$ yield. This procedure discovered by Lily Wang greatly improved the efficiency of the decarbonylation, as compared to an earlier reaction condition of using only ethanol, which under former condition usually takes more than two weeks. The diester $\mathbf{5 5}$ was treated with an excess amount of aqueous lithium hydroxide solution in THF at $60^{\circ} \mathrm{C}$ for 13 hours followed by acidification with $1 \mathrm{M}$ hydrochloric acid to give the corresponding diacid 54 in $94 \%$ yield. The diacid 54 was refluxed in thionyl chloride to provide the corresponding diacid chloride, which underwent two Friedel-Crafts reactions by treating with aluminum chloride in anhydrous methylene chloride to afford diketone $\mathbf{5 2}$ in $32 \%$ yield.

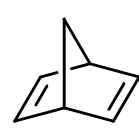

$\underset{-65^{\circ} \mathrm{C}}{\stackrel{\mathrm{KMnO}_{4} \text {, acetone }}{\longrightarrow}}$

60

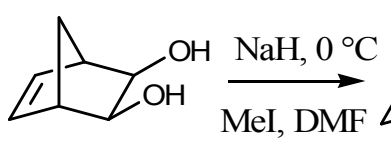

59

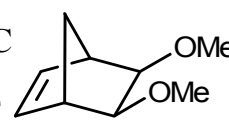

$58,39 \%$

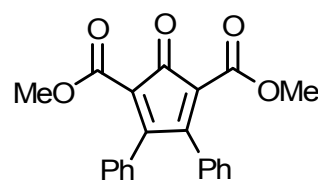

57 


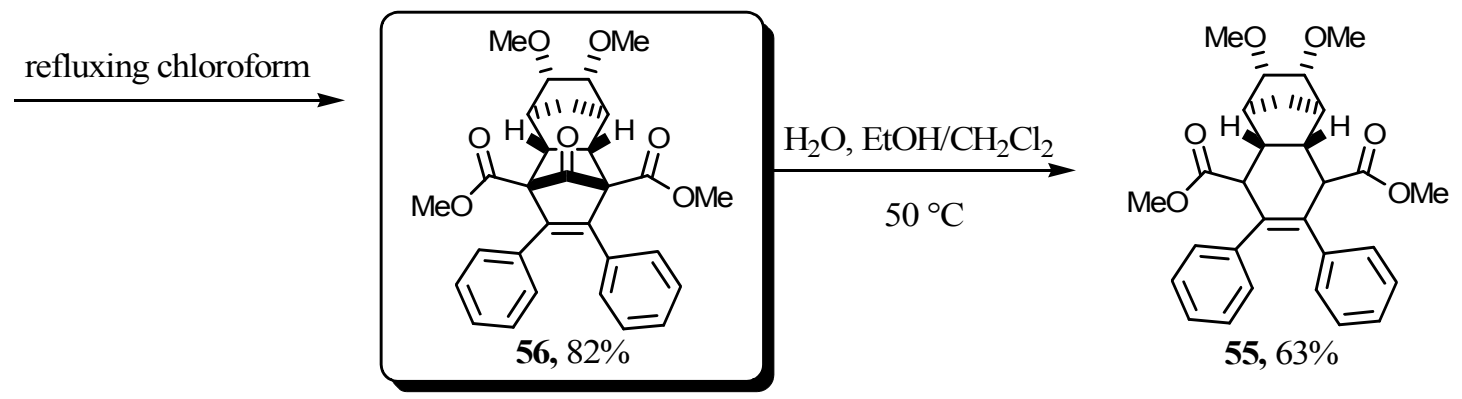

1. $\mathrm{LiOH}, \mathrm{THF}$

2. $\mathrm{HCl}$

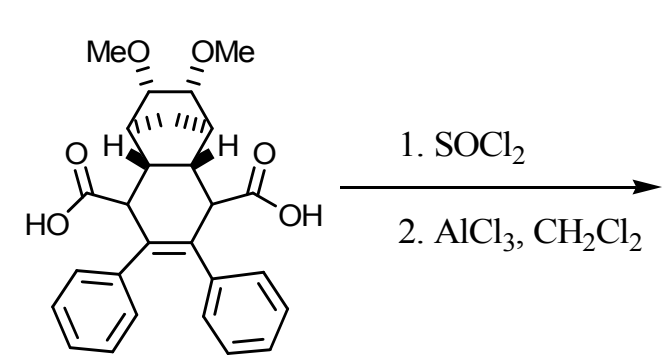

$\mathbf{5 4}, 94 \%$

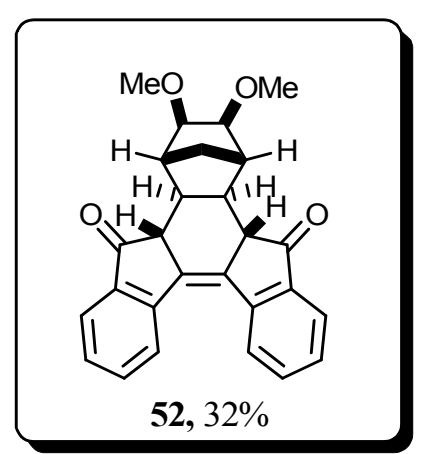

Scheme 6: Preparation of diketone 52

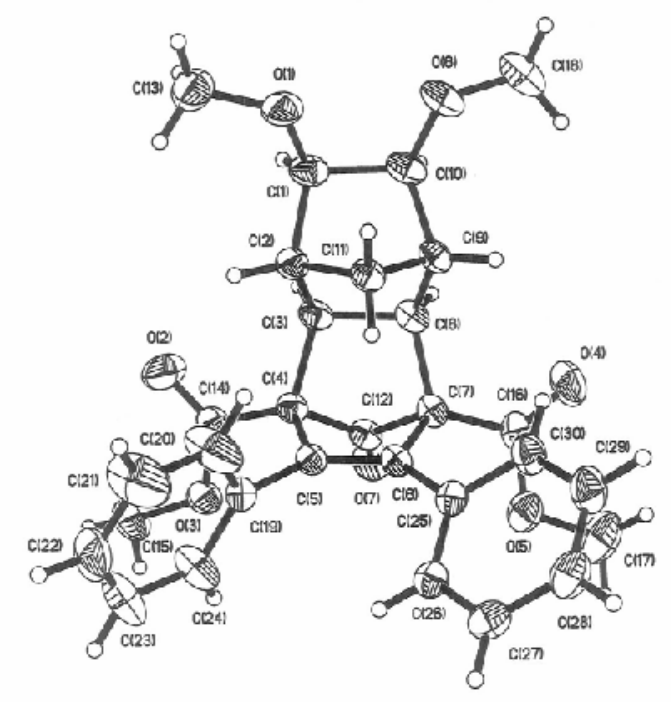

Figure 4: ORRTEP Drawing of the Crystal structures of $\mathbf{5 6}$

The stereochemistry of diketone $\mathbf{5 2}$ was confirmed by the NOSEY experiment. The six hydrogens on the norboryl ring still have the same orientations as diester 56. In the NOESY spectrum of diketone 52 (Figure 
5), the two a -hydrogens adjacent to the carbonyl groups $\left(\mathrm{H}_{1}\right.$ and $\left.\mathrm{H}_{7}\right)$ at $2.97 \mathrm{ppm}$ showed strong nOes to $\mathrm{H}_{3}$ and $\mathrm{H}_{9}$ protons at $3.11 \mathrm{ppm}$, and to $\mathrm{H}_{6}$ proton at $1.69 \mathrm{ppm}$. But, there are no nOes between $\mathrm{H}_{1}$ and $\mathrm{H}_{2}$ or between $\mathrm{H}_{1}$ and $\mathrm{H}_{4}$ protons, indicating that $\mathrm{H}_{1}$ and $\mathrm{H}_{7}$ protons are on the same side with the methylene bridge of norboryl ring.

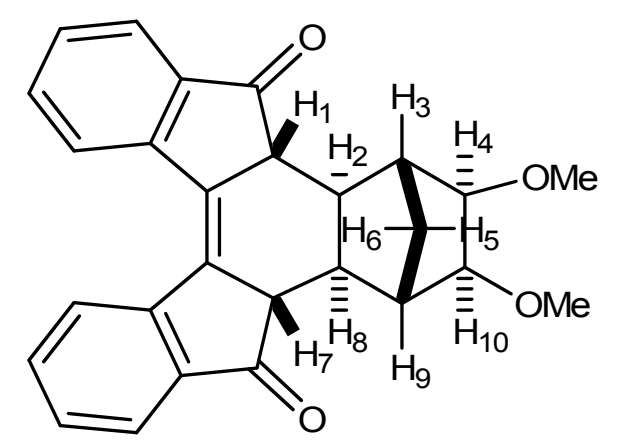

Figure 5: nOe of diketone 52

Diketone 52 was treated with 1 M lithium diisoproprylamide followed by iodomethane to afford diketone $\mathbf{5 1}$ in $41 \%$ yield. The stereochemistry of $\mathbf{5 1}$ was confirmed by NOSEY experiment.

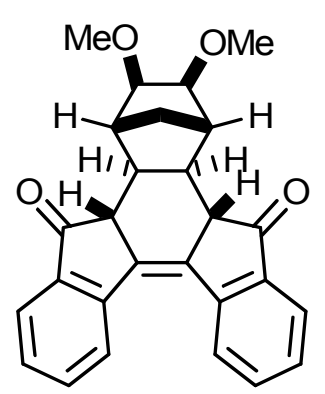

52

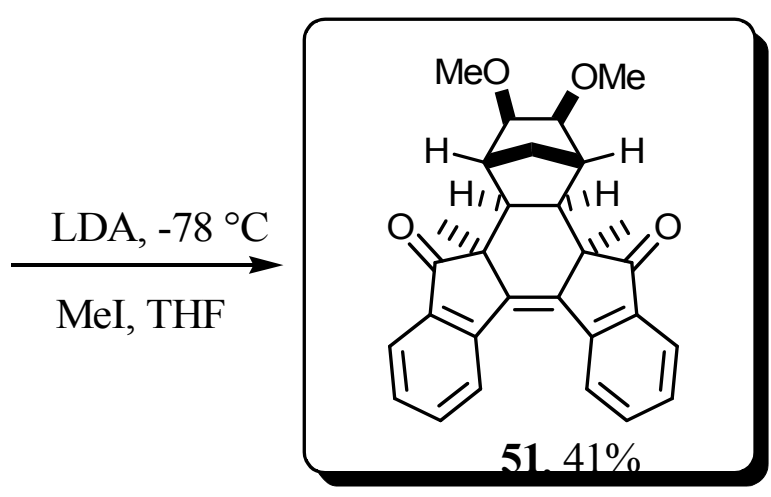

$51.41 \%$

Scheme 7: Preparation of diketone 51

In the NOESY spectrum of diketone 51 (Figure 6), the six protons of the two methyl groups on the a-carbons adjacent to the carbonyl groups at $1.58 \mathrm{ppm}$ showed strong nOes to $\mathrm{H}_{2}$ and $\mathrm{H}_{8}$ protons at $2.24 \mathrm{ppm}$, and to 
the $\mathrm{H}_{3}$ and $\mathrm{H}_{9}$ protons at $2.36 \mathrm{ppm}$. But, there are no nOes between the protons of the methyl groups and $\mathrm{H}_{6}$ proton. Therefore, the two methyl groups are on the opposite side with the methylene bridge of the norboryl ring.

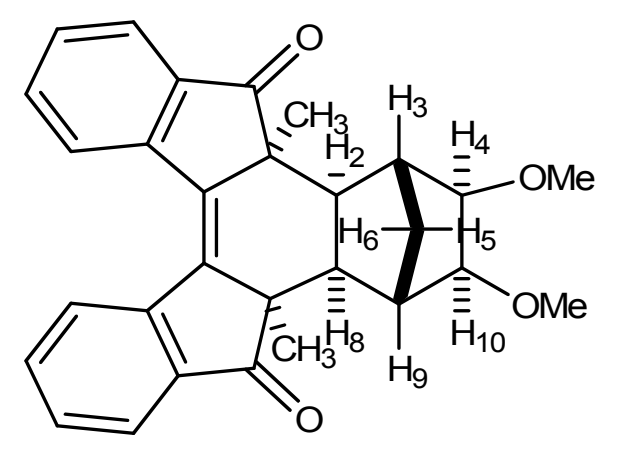

Figure 6: nOe of diketone 51

The condensation between diketone $\mathbf{5 1}$ and 3 equiv of $\mathbf{1 1}$ in distilled diethyl ether and benzene failed to afford diol 50. Presumably, due to steric crowding caused by the norboryl ring and two methyl groups, the lithium acetylide $\mathbf{1 1}$ was unable to attack the two carbonyl groups to give the product 50. A different synthetic strategy is needed to promote the reaction.

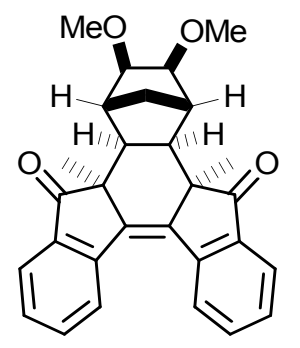

51

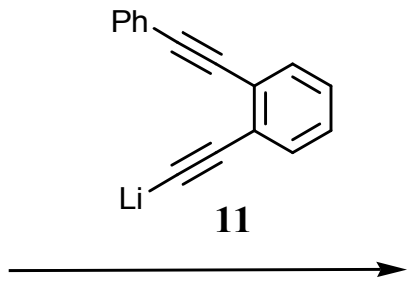

$\mathrm{Et}_{2} \mathrm{O} /$ benzene

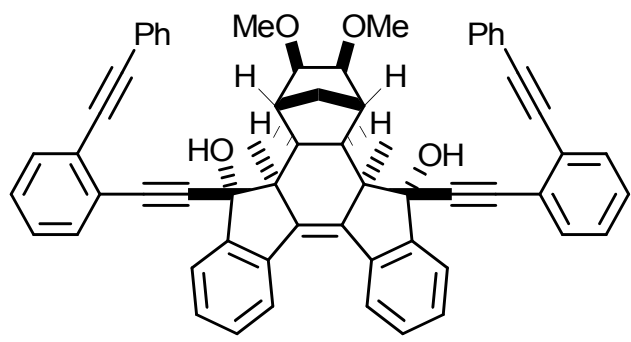

50

Scheme 8: Condensation Between Diketone 51 and Acetylide 11 


\section{Conclusions}

A simple and efficient pathway to synthesize novel nonplanar polycyclic aromatics was explored, and the key intermediate diketone $\mathbf{5 1}$ was successfully prepared. The diketone with a norboryl ring which could be easily opened in further steps could become a potential precursor for making a novel buckybasket. 


\section{Part II}

\section{Experimental Section}

General Methods and Materials. ${ }^{1} \mathrm{H}$ and ${ }^{13} \mathrm{C}$ NMR spectra were recoreded on a Varian VXR-600 (600 MHz) spectrometer. Chemical shifts are reported relative to $\mathrm{CDCl}_{3}(\delta 7.26 \mathrm{ppm})$ for ${ }^{1} \mathrm{H}$ and $\mathrm{CDCl}_{3}(\delta 77.0 \mathrm{ppm})$ for ${ }^{13} \mathrm{C}$. Infrared (IR) Spectra were obtained on a FT-IR spectrometer. Melting Points were determined with Eledtrothermal Mel-Temp apparatus and are uncorrected. Flash column chromatagraphy was performed on ICN reagent 60 (60-200 mesh) silica gel. Analytical thin-layer chromatography was performed with precoated glass-backed plates (Whatman K6F 60 , $\left.F_{254}\right)$ and visualized by UV-lamp at $254 \mathrm{~nm}$. $R_{\mathrm{f}}$ values are obtained by elution in the stated solvent ratios (v/v). Diethyl ether, THF, benezene and triethylamine were dried by passing through activated alumina column with argon gas pressure. Anhydrous diethyl ether, THF and benzene were distilled from benezephenone ketyl prior to use. Methylene Chloride was distilled from $\mathrm{CaH}_{2}$. Commercial regents were used without purification unless otherwise noted. Air and/or moisture-sensitive reactions were carried out under an atmosphere of argon/nitrogen using oven-dried glassware and standard syringe/septa techniques. 
Exo-cis-5,6-dimethoxy-2-Norbornene (57). To a vigorously stirred solution of sodium hydride ( $60 \%$ in mineral oil, $2.51 \mathrm{~g}, 62.9 \mathrm{mmol})$ in DMF $(50 \mathrm{~mL})$ at $0 \quad{ }^{\circ} \mathrm{C}$ was added dropwise $1.98 \mathrm{~g}$ of exo-cis-5-norbornene-2,3-diol $59(15.7 \mathrm{mmol})$ in dry $N, N$-dimethyl-formamide (DMF, $20 \mathrm{~mL}$ ). After the addition, the mixture was allowed to warm to room temperature and stirred vigorously until a homogeneous solution was obtained. After 30 minutes, the solution was cooled to $0{ }^{\circ} \mathrm{C}$ and $15.06 \mathrm{~mL}$ of iodomethane $(78.5 \mathrm{mmol})$ was added dropwise with stirring. After additional 7 hours at room temperature, $80 \mathrm{~mL}$ of water was introduced slowly and the reaction mixture was extracted with diethyl ether. The combined organic extracts were washed with brine and water, dried over sodium sulfate and diethyl ether was evaporated by rotary evaporator. The residue was further purified by distillation at $190{ }^{\circ} \mathrm{C}$ to give exo-cis-2,3-dimethoxy-5-norbornene $(58,0.95 \mathrm{~g})$ as a clear yellow oil (6.2 mmol, 39\%): ${ }^{1} \mathrm{H}$ NMR $\left(600 \mathrm{MHz}, \mathrm{CDCl}_{3}\right) \delta 6.03(2 \mathrm{H}, \mathrm{t}, \quad J=1.8$ Hz), 3.44 (6H, s), 3.34 (2H, d, $J=1.8 \mathrm{~Hz}), 2.85(2 \mathrm{H}, \mathrm{t}, J=1.2 \mathrm{~Hz}), 1.95(1 \mathrm{H}$, $\mathrm{d}, J=8.4 \mathrm{~Hz}), 1.61\left(1 \mathrm{H}, \mathrm{dt}, J_{\mathrm{d}}=9 \mathrm{~Hz}, J_{\mathrm{t}}=1.8 \mathrm{~Hz}\right) ;{ }^{13} \mathrm{C}$ NMR $\delta(150 \mathrm{MHz}$, $\left.\mathrm{CDCl}_{3}\right) \delta 136.7,79.4,58.3,44.3,43.3$.

Diels-Alder Adduct 56. A mixture of $0.25 \mathrm{~g}$ of 2,5-dicarbomethoxy-3,4-

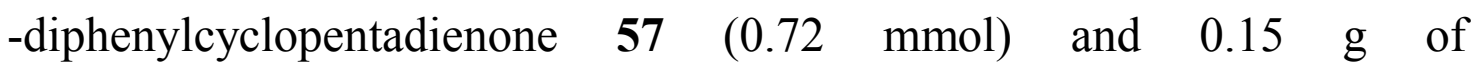
exo-cis-5,6-dimethoxy-2-norbornene $58(0.97 \mathrm{mmol})$ in $15 \mathrm{~mL}$ of 
chloroform was heated under reflux for 15 hours. The solvent was removed in vacuo. The residue was purified by recrystallization from methylene chloride and hexanes to afford $0.25 \mathrm{~g}$ of diester 56 as a white solid (0.50 mmol, 82\%): $\mathrm{mp} 176.9-178.5{ }^{\circ} \mathrm{C}$; IR (thin film, $\mathrm{cm}^{-1}$ ) 2922, 1737, 1456, 1092, 699; ${ }^{1} \mathrm{H}$ NMR $\left(600 \mathrm{M} \mathrm{Hz}, \mathrm{CDCl}_{3}\right) \delta$ 7.24-7.22 (6H, m), 7.14-7.13 (4H, m), $3.56(6 \mathrm{H}, \mathrm{s}), 3.45(6 \mathrm{H}, \mathrm{s}), 2.79(2 \mathrm{H}, \mathrm{s}), 2.56(2 \mathrm{H}, \mathrm{s})$, $1.99(2 \mathrm{H}, \mathrm{s}), 1.92(1 \mathrm{H}, \mathrm{d}, J=11.4 \mathrm{~Hz}), 1.70(1 \mathrm{H}, \mathrm{d}, J=11.4 \mathrm{~Hz}) ; \quad{ }^{13} \mathrm{C}$ NMR $\left(150 \mathrm{MHz}, \mathrm{CDCl}_{3}\right) \delta 1896.2,167.8,136.1,133.5,128.4,128.3,128.2$ 86.3, 67.9, 58.8, 52.2, 42.7, 41.6, 29.7; CIHRMS: calculated for $\left[\mathrm{C}_{30} \mathrm{H}_{30} \mathrm{O}_{7}+\mathrm{H}\right]^{+}:$503.2070, found $\left[\mathrm{C}_{30} \mathrm{H}_{30} \mathrm{O}_{7}+\mathrm{H}\right]^{+}:$503.20698; calculated $\left[\mathrm{C}_{30} \mathrm{H}_{30} \mathrm{O}_{7}+\mathrm{Na}\right]^{+}:$525.18883; found $\left[\mathrm{C}_{30} \mathrm{H}_{30} \mathrm{O}_{7}+\mathrm{Na}\right]^{+}: 525.18892$.

Diester 55. To a solution of $0.427 \mathrm{~g}$ of diester $56(0.90 \mathrm{mmol})$ in $3 \mathrm{~mL}$ of methylene chloride was added $15 \mathrm{~mL}$ of ethanol and $10 \mathrm{~mL}$ of water. The mixture was stirred at $50{ }^{\circ} \mathrm{C}$ for 15 hours. The resulting solution was extracted three times with methylene chloride. The combined organic layers were washed with brine, water, dried over sodium sulfate, and concentrated. The residue was purified by flash column chromatography ( silica gel/ethyl acetate:methylene chloride:hexanes $=3: 5: 5$ ) to provide $0.27 \mathrm{~g}$ of diester $\mathbf{5 5}$ as a white solid( $0.57 \mathrm{mmol}, 63 \%)$ : IR (thin film, $\left.\mathrm{cm}^{-1}\right) 1731,1265,1198,1120,700 ;{ }^{1} \mathrm{H}$ NMR $\left(600 \mathrm{MHz}, \mathrm{CDCl}_{3}\right) \delta$ 7.10-7.04 (6H, m), 6.88-6.86 (4H, m), 3.70(2H, q, $J=2.4 \mathrm{~Hz}), 3.45(6 \mathrm{H}, \mathrm{s})$, 
$3.42(2 \mathrm{H}, \mathrm{s}), 3.39(2 \mathrm{H}, \mathrm{s}), 3.35(6 \mathrm{H}, \mathrm{s}), 2.99(2 \mathrm{H}, \mathrm{s}), 1.94-1.91(1 \mathrm{H}, \mathrm{d}$, $J=11.4 \mathrm{~Hz}), 1.74-1.72(1 \mathrm{H}, \mathrm{d}, J=11.4 \mathrm{~Hz}) ;{ }^{13} \mathrm{C} \mathrm{NMR}\left(150 \mathrm{MHz}, \mathrm{CDCl}_{3}\right) \delta$ $172.4,139.8,135.9,128.6,127.5,126.3,86.1,58.5,51.4,48.9,42.9,40.8$, 30.9 .

Diacid 54. To a solution of $0.26 \mathrm{~g}$ of diester $55(0.571 \mathrm{mmol})$ in $8 \mathrm{~mL}$ of THF was added an aqueous lithium hydroxide solution $(4.7 \mathrm{~mL}, 1.0 \mathrm{M})$. The resulting solution was stirred at $60{ }^{\circ} \mathrm{C}$ for 13 hours and then concentrated under reduced pressure. The residue was neutralized with 1 M hydrochloric acid and extracted with methylene chloride. The organic layer was washed with brine, water, dried over sodium sulfate, and concentrated to afford $0.24 \mathrm{~g}$ of diacid $\mathbf{5 4}$ as white solid $(0.537 \mathrm{mmol}$, 94\%): $\mathrm{mp} 192.6-193.4{ }^{\circ} \mathrm{C}$; IR (thin film, $\mathrm{cm}^{-1}$ ) 2932, 1703, 1095, 697; ${ }^{1} \mathrm{H}$ NMR $\left(600 \mathrm{MHz}, \mathrm{CDCl}_{3}\right) \delta$ 7.16-7.13 (10H, m), $3.66(2 \mathrm{H}, \mathrm{s}), 3.50(2 \mathrm{H}, \mathrm{s})$, $3.42(6 \mathrm{H}, \mathrm{s}), 2.67(2 \mathrm{H}, \mathrm{s}), 2.28(2 \mathrm{H}, \mathrm{s}), 1.98(1 \mathrm{H}, \mathrm{d}, J=10.2 \mathrm{~Hz}), 1.71(1 \mathrm{H}$, $\mathrm{d}, J=10.2 \mathrm{~Hz}), 1.57(1 \mathrm{H}, \mathrm{s}) ;{ }^{13} \mathrm{C}$ NMR $\left(150 \mathrm{MHz}, \mathrm{CDCl}_{3}\right) \delta 179.8,141.8$, 135.8, 129.1, 128.0, 126.9, 58.6, 52.0, 47.4, 39.9, 30.4; CIHRMS: calculated for $\left[\mathrm{C}_{27} \mathrm{H}_{28} \mathrm{O}_{6}+\mathrm{H}\right]^{+}:$449.1964, found $\left[\mathrm{C}_{27} \mathrm{H}_{28} \mathrm{O}_{6}+\mathrm{H}\right]^{+}$: 449.19642; calculated for $\left[\mathrm{C}_{27} \mathrm{H}_{28} \mathrm{O}_{6}+\mathrm{Na}\right]^{+}:$471.17823, found $\left[\mathrm{C}_{27} \mathrm{H}_{28} \mathrm{O}_{6}+\mathrm{Na}\right]^{+}$: 471.17836

Diketone 52. A solution of $0.482 \mathrm{~g}$ of acid $(1.07 \mathrm{mmol})$ in $4 \mathrm{~mL}$ thionyl 
chloride was heated under reflux for 12 hours. Then thionyl chloride was removed in vacuo. The residue was dissolved in $40 \mathrm{~mL}$ of anhydrous methylene chloride at $0{ }^{\circ} \mathrm{C}$ and $0.43 \mathrm{~g}$ of anhydrous aluminum chloride (3.22 mmol) was added slowly. After 2 hours at $0{ }^{\circ} \mathrm{C}$, the reaction mixture was allowed to warm to room temperature. After an additional 5 hours at room temperature, $15 \mathrm{~mL}$ of a saturated ammonium chloride solution was introduced slowly and the organic layer was separated. The aqueous layer was back extracted with diethyl ether. The combined organic layers were washed with brine, water, dried over sodium sulfate, and concentrated. The residue was purified by flash column chromatography (silica gel/ethyl acetate:methylene chloride:hexane $=2: 5: 5)$ to provide $0.140 \mathrm{~g}$ of diketone 52 as yellow solid (0.34 mmol, 32\%): $\mathrm{mp} 278.8-280.1{ }^{\circ} \mathrm{C}$; IR (thin film, $\left.\mathrm{cm}^{-1}\right) 1702,1090,761 ;{ }^{1} \mathrm{H}$ NMR $\left(600 \mathrm{M} \mathrm{Hz}, \mathrm{CDCl}_{3}\right) \delta 8.35(2 \mathrm{H}, \mathrm{d}, J=7.8$ Hz), $7.91(2 \mathrm{H}, \mathrm{d}, J=7.8 \mathrm{~Hz}), 7.77(2 \mathrm{H}, \mathrm{t}, J=7.8 \mathrm{~Hz}), 7.53(2 \mathrm{H}, \mathrm{t}, J=7.8 \mathrm{~Hz})$, $3.50(6 \mathrm{H}, \mathrm{s}), 3.38(2 \mathrm{H}, \mathrm{d}, J=1.2 \mathrm{~Hz}), 3.11(2 \mathrm{H}, \mathrm{s}), 2.97\left(2 \mathrm{H}, \mathrm{dd}, J_{\mathrm{d}}=10.2\right.$ $\left.\mathrm{Hz}, J_{\mathrm{d}}=2.4 \mathrm{~Hz}\right), 1.96(1 \mathrm{H}, \mathrm{d}, J=12 \mathrm{~Hz}), 1.68(1 \mathrm{H}, \mathrm{d}, J=12 \mathrm{~Hz}), 1.65(2 \mathrm{H}, \mathrm{d}$, $J=9 \mathrm{~Hz}) ;{ }^{13} \mathrm{C} \mathrm{NMR}\left(600 \mathrm{M} \mathrm{Hz}, \mathrm{CDCl}_{3}\right) \delta 203.2,145.7,138.1,135.2,132.4$, 129.6, 124.8, 124.6, 84.9, 58.6, 51.8, 43.7, 42.6, 27.1; CIHRMS: calculated for $\left[\mathrm{C}_{27} \mathrm{H}_{24} \mathrm{O}_{4}+\mathrm{H}\right]^{+}:$413.1753., found $\left[\mathrm{C}_{27} \mathrm{H}_{24} \mathrm{O}_{4}+\mathrm{H}\right]^{+}$: 413.17529, calculated for $\left[\mathrm{C}_{27} \mathrm{H}_{24} \mathrm{O}_{4}+\mathrm{Na}\right]^{+}:$435.15713., found $\left[\mathrm{C}_{27} \mathrm{H}_{24} \mathrm{O}_{4}+\mathrm{Na}\right]^{+}: 435.15723$. 
Diketone 51. To a solution of $0.140 \mathrm{~g}(0.35 \mathrm{mmol})$ of diketone 52 in 30 $\mathrm{mL}$ of anhydrous THF under a nitrogen atmosphere at $-78{ }^{\circ} \mathrm{C}$ was added $1.05 \mathrm{~mL}$ of a $1 \mathrm{M}$ solution of lithium diisopropylamide $(1.05 \mathrm{mmol})$ in THF $/ n$-heptane. After 30 minutes of stirring, $0.12 \mathrm{~mL}$ of iodomethane was added. After an additional $13 \mathrm{~h}, 30 \mathrm{~mL}$ of a saturated ammonium chloride solution was introduced, and the reaction mixture was extracted with diethyl ether. The combined organic extracts were washed with brine and water, dried over sodium sulfate, and concentrated. The residue was purified by flash column chromatography (silica gel/ethyl acetate:methylene chloride:hexanes $=1: 2: 2$ ) to provide $0.064 \mathrm{~g}$ of diketone 51 as a red-brown oil (0.145 mmol, 41\%): IR (thin film, $\left.\mathrm{cm}^{-1}\right)$ 1712, 1264, 734; ${ }^{1} \mathrm{H}$ NMR (600 MHz, $\left.\mathrm{CDCl}_{3}\right) \delta 8.40(2 \mathrm{H}, \mathrm{d}, J=7.8 \mathrm{~Hz}), 7.92(2 \mathrm{H}, \mathrm{d}$, $J=7.2 \mathrm{~Hz}), 7.73(2 \mathrm{H}, \mathrm{t}, J=7.2 \mathrm{~Hz}), 7.53(2 \mathrm{H}, \mathrm{t}, J=7.2 \mathrm{~Hz}), 3.39(2 \mathrm{H}, \mathrm{d}$, $J=1.2 \mathrm{~Hz}), 3.36(6 \mathrm{H}, \mathrm{s}), 2.37(2 \mathrm{H}, \mathrm{s}), 2.25(2 \mathrm{H}, \mathrm{s}), 1.59(6 \mathrm{H}, \mathrm{s}), 1.11(1 \mathrm{H}$, $\mathrm{d}, J=10.8 \mathrm{~Hz}), 0.58(1 \mathrm{H}, \mathrm{d}, J=10.8 \mathrm{~Hz}) ;{ }^{13} \mathrm{C} \quad \mathrm{NMR}\left(600 \mathrm{M} \mathrm{Hz}, \mathrm{CDCl}_{3}\right) \delta$ 206.9, 146.4, 138.4, 135.9, 134.8, 129.8, 125.3, 124.9, 85.0, 58.4, 54.9, 46.4, 43.8, 29.5, 27.9; CIHRMS: calculated for $\left[\mathrm{C}_{29} \mathrm{H}_{28} \mathrm{O}_{4}+\mathrm{H}\right]^{+}$: 441.2076, found: $\left[\mathrm{C}_{27} \mathrm{H}_{28} \mathrm{O}_{6}+\mathrm{H}\right]^{+}$: 441.20659; calculated for $\left[\mathrm{C}_{29} \mathrm{H}_{28} \mathrm{O}_{4}+\mathrm{Na}\right]^{+}$: 463.18943, $\left[\mathrm{C}_{27} \mathrm{H}_{28} \mathrm{O}_{6}+\mathrm{Na}\right]^{+}: 463.18853$. 


\section{Reference:}

1 Kroto, H. W.; Heath, J. R.; O’Brien, S. C.; Curl, R. F,; Smalley, R. E. Nature. 1985, 318, 162.

2 Rabideau, P. W.; Sygula, A. Acc. Chem. Res. 1996, 29, 235 and references therein.

3 Bath, W. E.; Lowton, R. G.; J. Am. Chem. Soc. 1996, 88, 380. (b) Scott, L. T. Pure and Appl. Chem. 1996, 68, 291.

4 (a) Sygula, A.; Abdourazak, A. H.; Raibideau, P. W. J. Am. Chem. Soc. 1996, 118, 339. (b) Sygula, A.; Raibideau, P. W. J. Am. Chem. Soc. 1999, 121, 7800. (c) Seiders, T. J.; Elliott, E. L.; Grube, G. H. J. Am. Chem. Soc. 1999, 121,7804 .

5 (a) Vikki, M. T.; Lawerence; T. S. Chem. Rev. 2006, 106,4868. (b) Scott, L. T. Pure and Appl. Chem. 1996, 68, 291. (c) Mehta, G.; Rao, H. S. P. Tetrahedron. 1998, 54, 13325. (d) Scott, L. T.; Hashemi, M. M.; Meyer, D. T.; Warren, H. B. J. Am. Chem. Soc. 1991, 113, 7082.

6 (a) Sygula, A.; Abdourazak, A. H.; Raibideau, P. W. J. Am. Chem. Soc. 1994, 116, 7891. (b) Clayton, M.D,; Marcinow, Z., Raibideau, P. W. J. Org. Chem. 1996, 61, 6052. (c) Mehta, G. Chem. Commun. 1997, 2081. (d) Sygula, A.; Abdourazak, A. H.; Raibideau, P. W. J. Am. Chem. Soc. 1998, 120, 12666.

7 (a) Meyer, D. T. M.S. Thesis, University of Neveda, Reno, 1991. (b) Bratcher, M.S. Ph.D. Dissertation, Boston College, Chestnut Hill, MA, 
1996. (c) McMahan, B. J. B. S. Thesis, Boston College, Chestnut Hill, MA, 1997. (d) Mehta, G.; Srirama Sarma, P. V. V. Chem. Commun. 2001, 19.

8 Seiders. T. J.; Baldridge, K. K.; O’Connor, J. M.; Siegel, J. S. J. Am. Chem. Soc. 1997, 119, 4781.

9 (a) Sygula, A.; Xu, G.; Marcinow, Z.; Rabideau, P. W. Tetrahedron, 2001, 57, 3637. (b) Alvarez, C. M.; Aneglici, R. J.; Sygula, R.; Sygula, A.; Rabideau, P. W. Organometallics, 2003, 22, 624 and references therein. 10 Vecci, P. A. ; Alvarez, C. M.; Ellern, A.; Aneglici, R. J.; Sygula, R.; Sygula, A.; Rabideau, P. W. Angew. Chem., Int. Ed. 2004, 43, 4497.

11 (a) Seiders. T. J.; Baldridge, K. K.; O’Connor, J. M.; Siegel, J. S. Chem. Commun. 2001, 951. (b) Nunzi, F.; Sgamellotti, A; Re, N. Organometallics, 2002, 21, 2219. (c) Sygula, A.; Rabideau, P. W. J. Chem. Soc., Chem. Commun., 1994, 2271.

12 (a) Zhang, H. R.; Wang, K. K. J. Org. Chem. 1999, 64, 7996. (b) Zhang, H. R.; Ph. D. Dissertation, West Virginia University, 2000. (c) Seiders, T. J.; Baldrige, K. K.; Siegel, J. S. J. Am. Chem. Soc. 1996, 118, 2754. (d) Hongbin Li; Wang, K. K. J. Org. Chem. 2001, 66, 6662. (e) Wang, K. K. Chem. Rev. 1996, 96, 207. (f) Wang, K. K,; Zhang, H. R.; Petersen, J. L. J. Org. Chem. 1999, 64, 1650.

13 Jacobs, T. L.; Fenton, D. M. J. Org. Chem. 1965, 30, 1808.

14 Yang, Y.; Wang, K. K.; Petersen, J. L. J. Org. Chem. 2006, 8, 
2313-2316.

15 Han, X.; Zhang, Y.; Wang, K. K. J. Org. Chem. 2005, 7, 2406-2408.

16 Yang, H, Ph. D. Dissertation, West Virginia University, 2006.

17 Shealy, Y. F., Clayton, J. D.; Tetrahedro letters. 1994, 35, 509-512.

18 White, D. M. J. Org. Chem. 1974, 39, 1951-1952. 
APPENDIX 


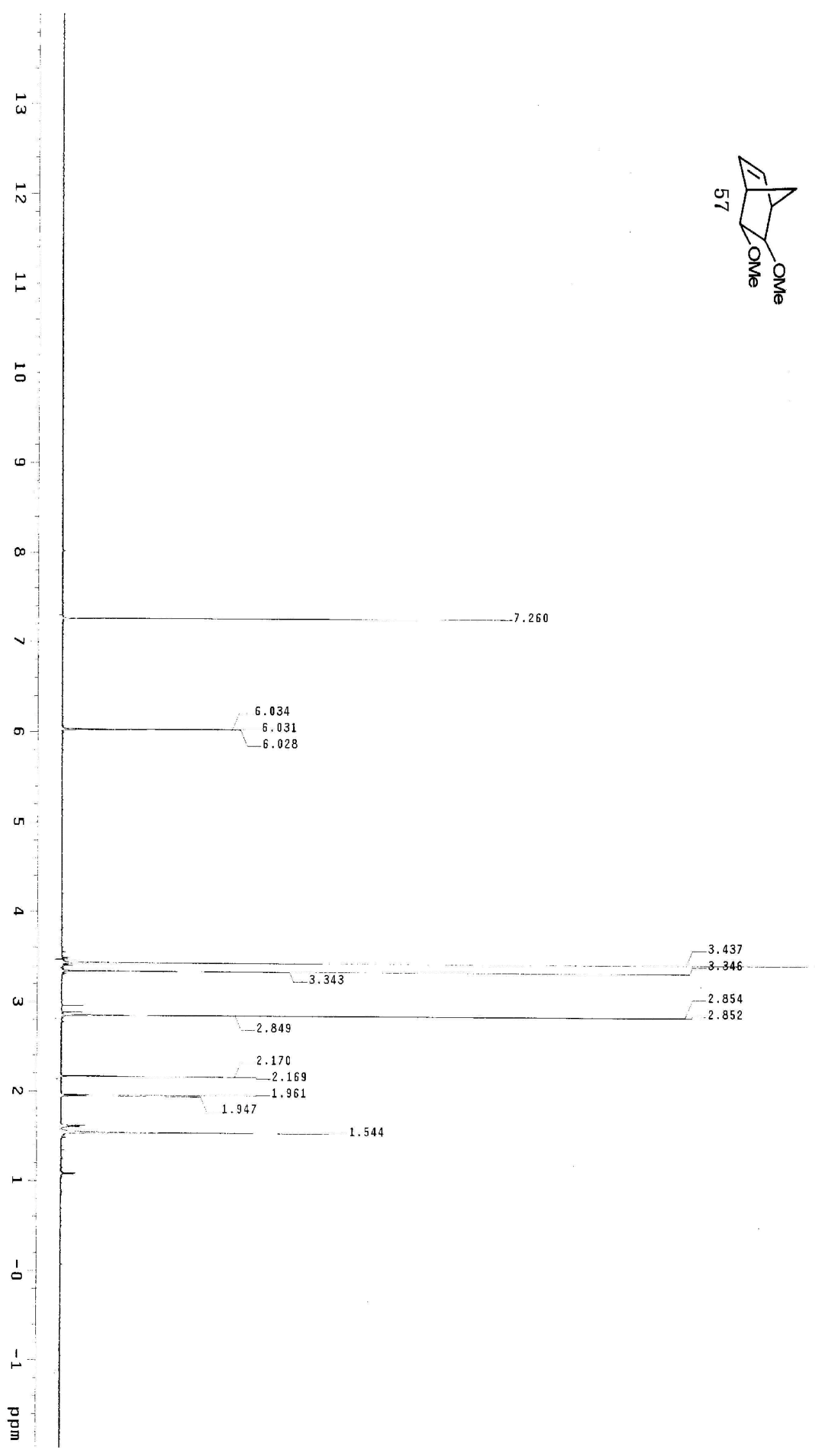




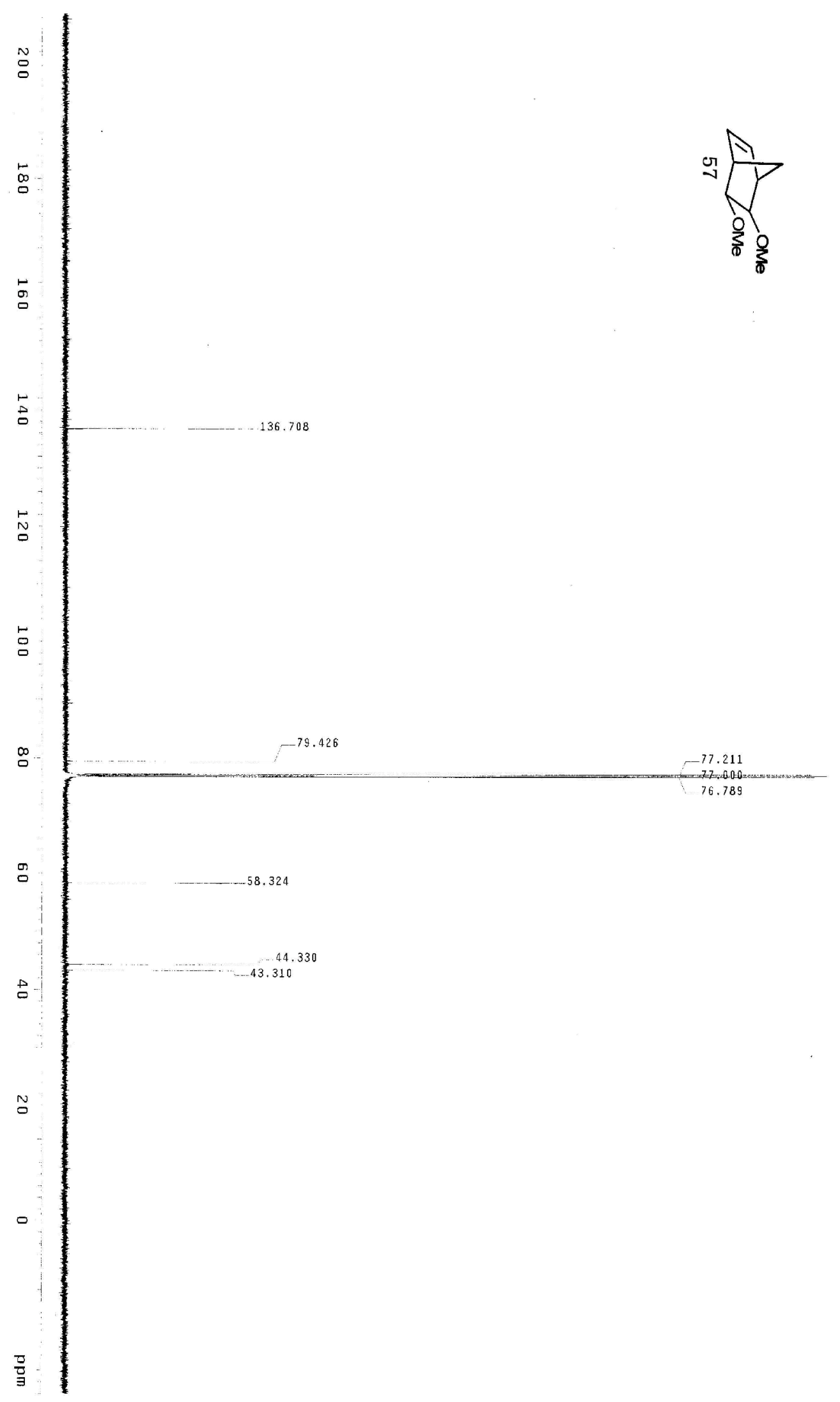




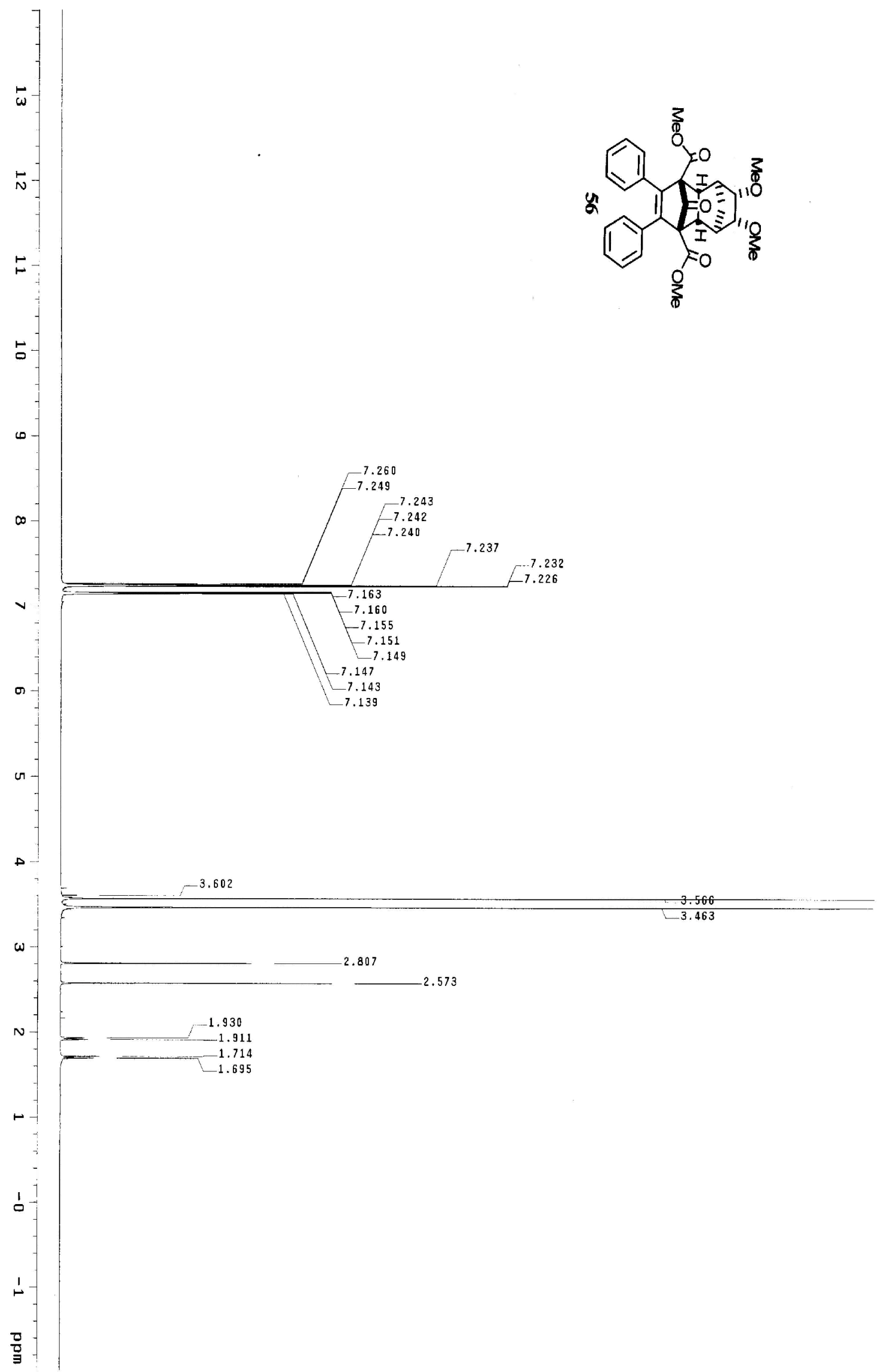




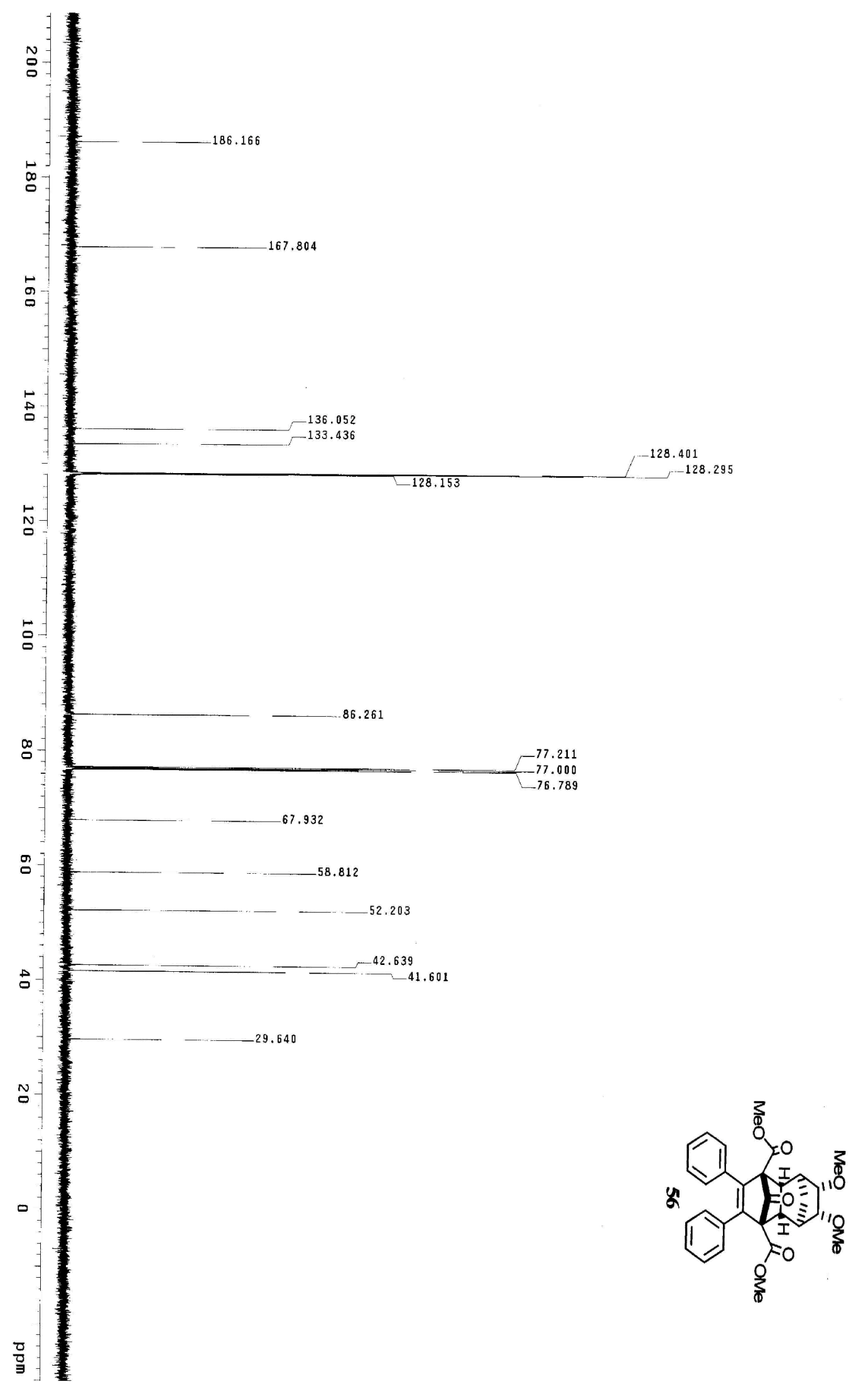




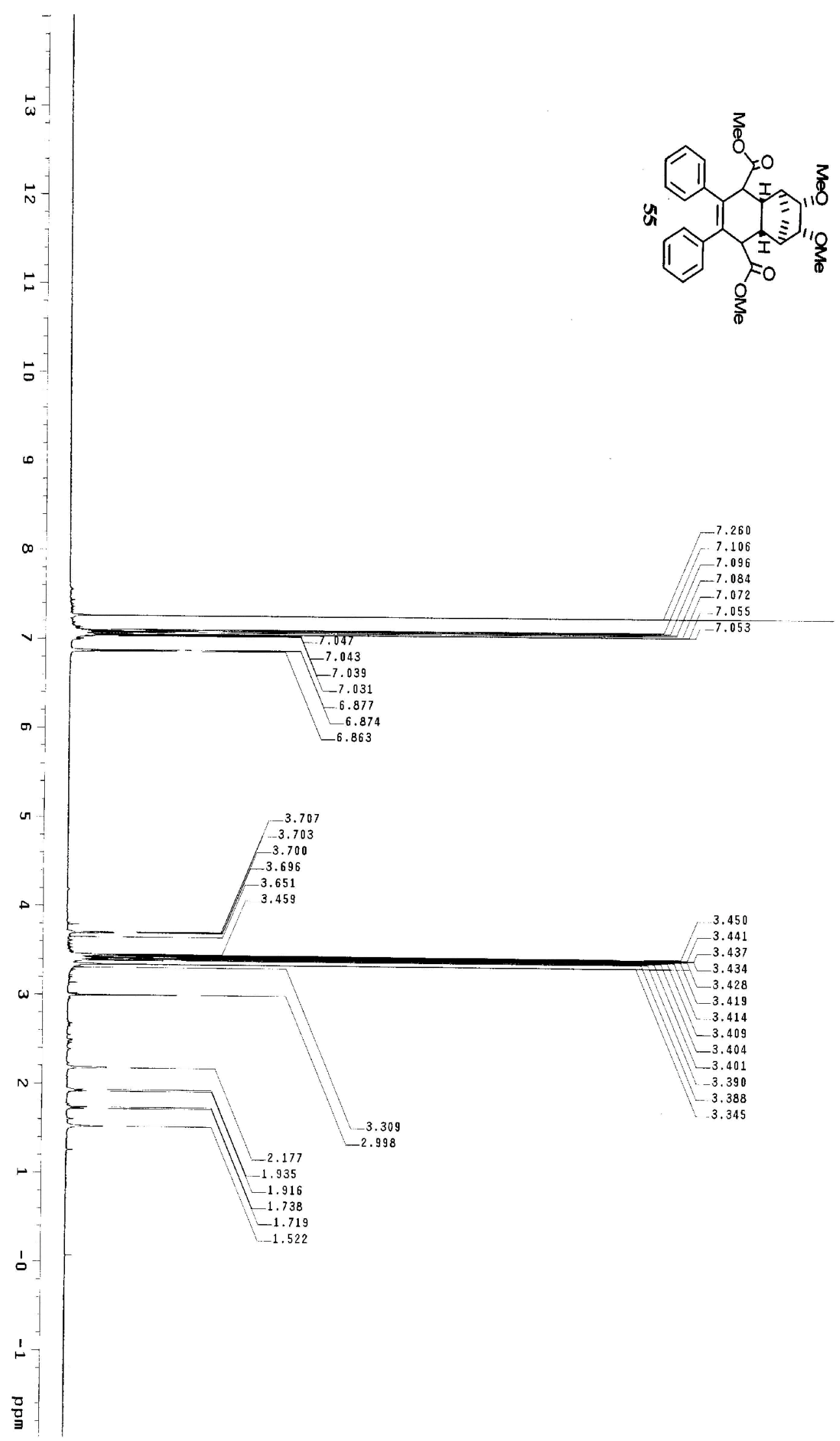




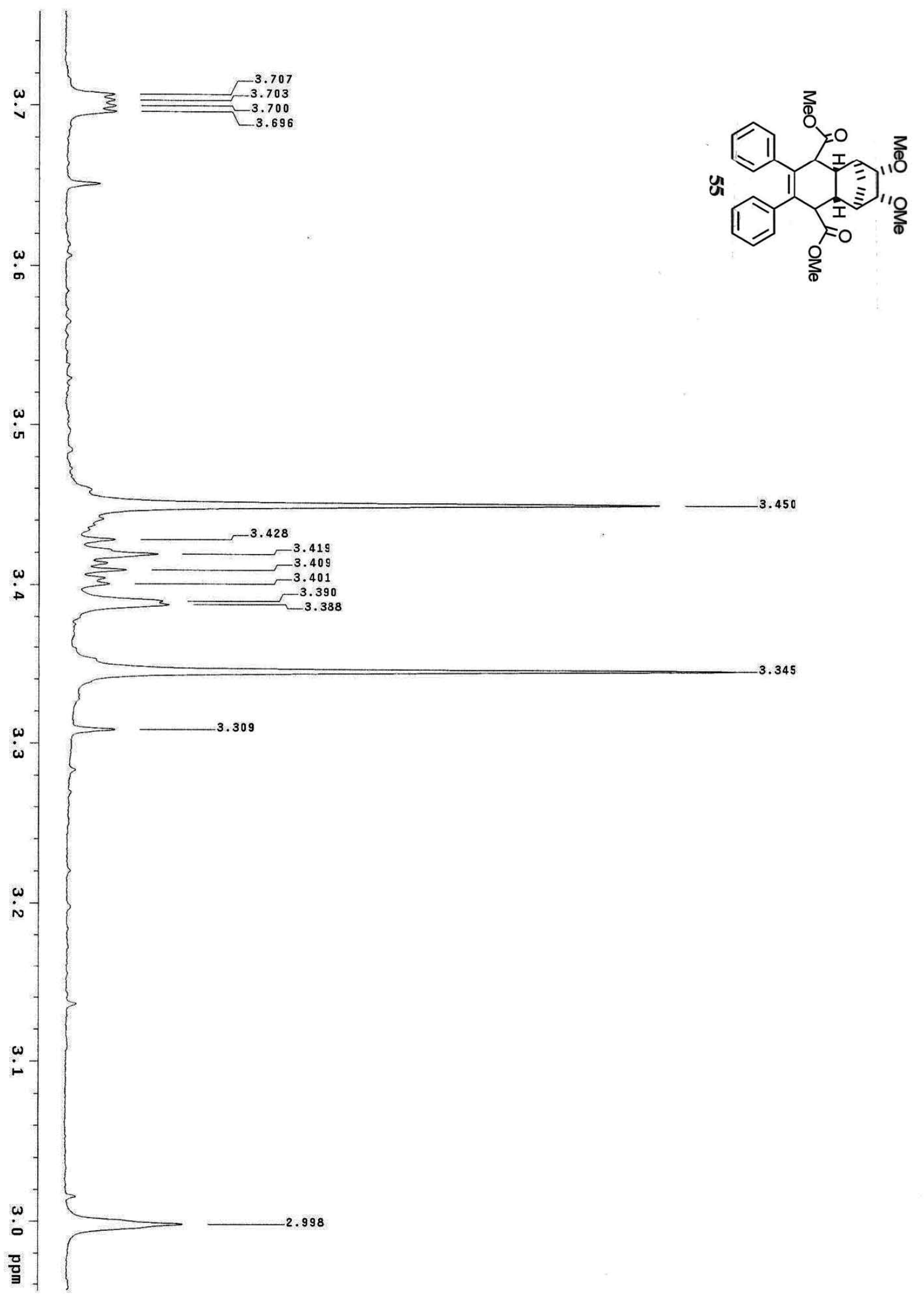




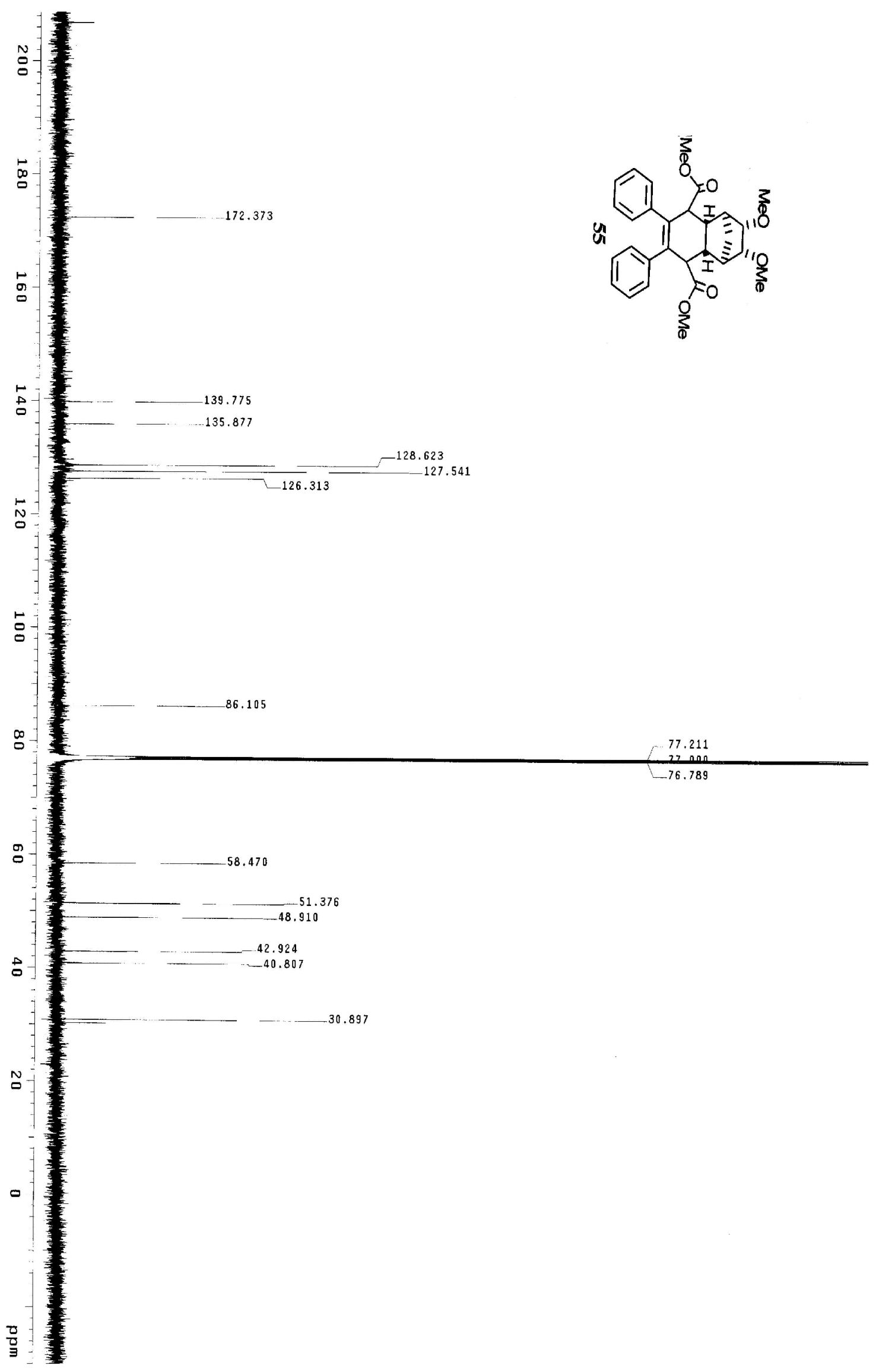




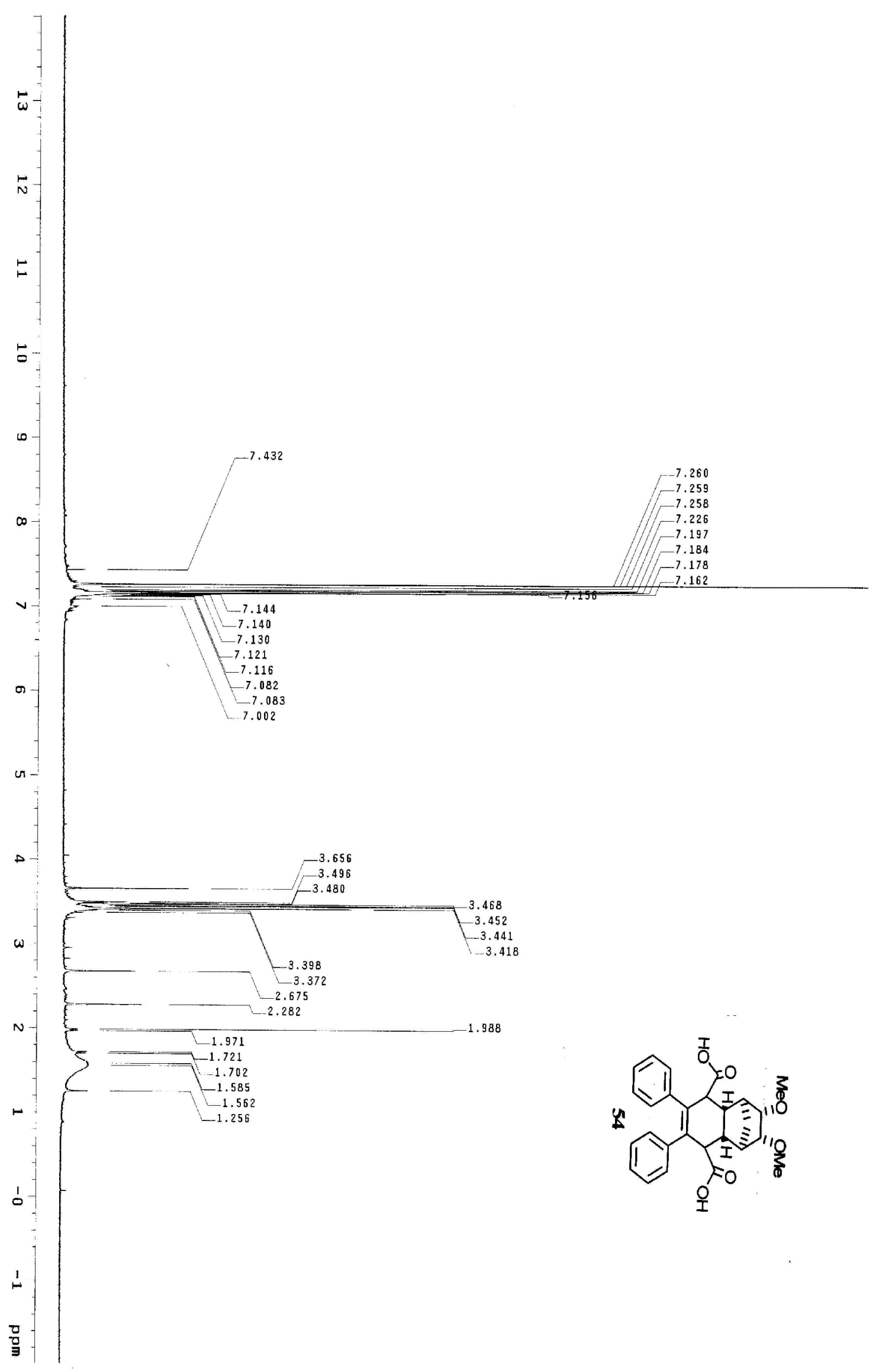




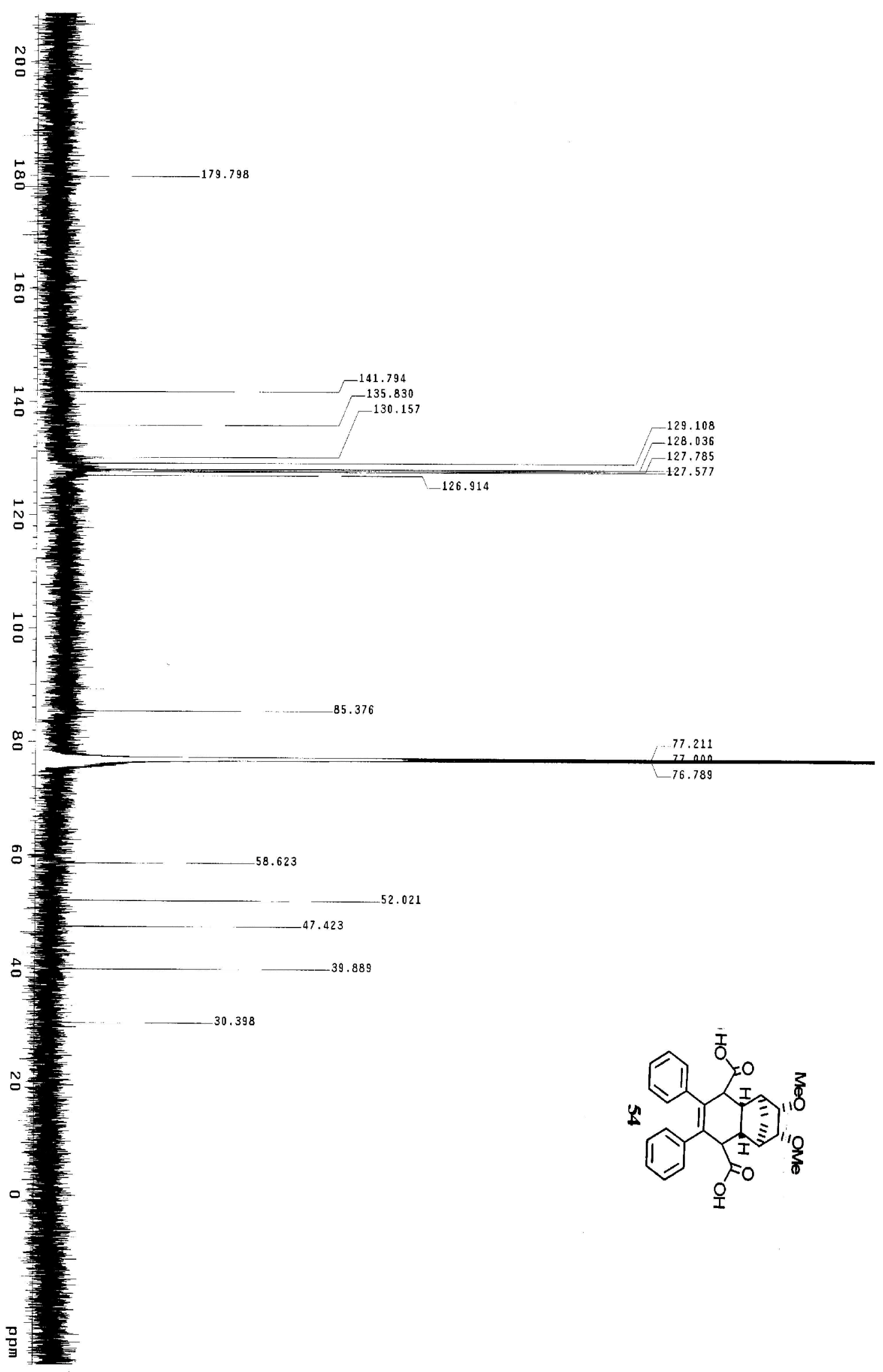




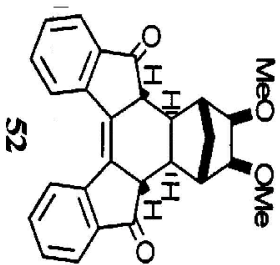

๖-

$\infty$

$\infty$

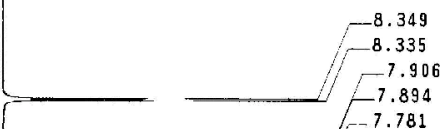

$\longrightarrow+7.780$

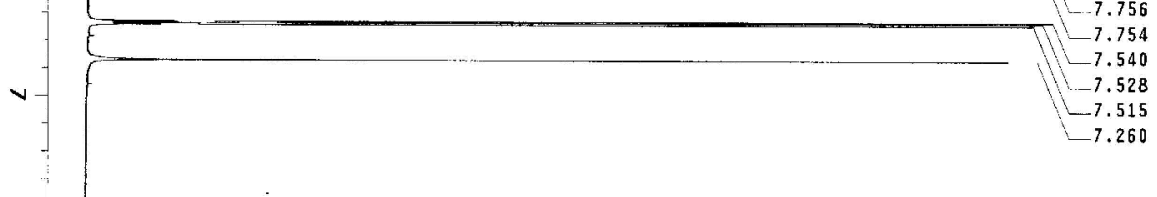

$\pi$

u

$\Delta$

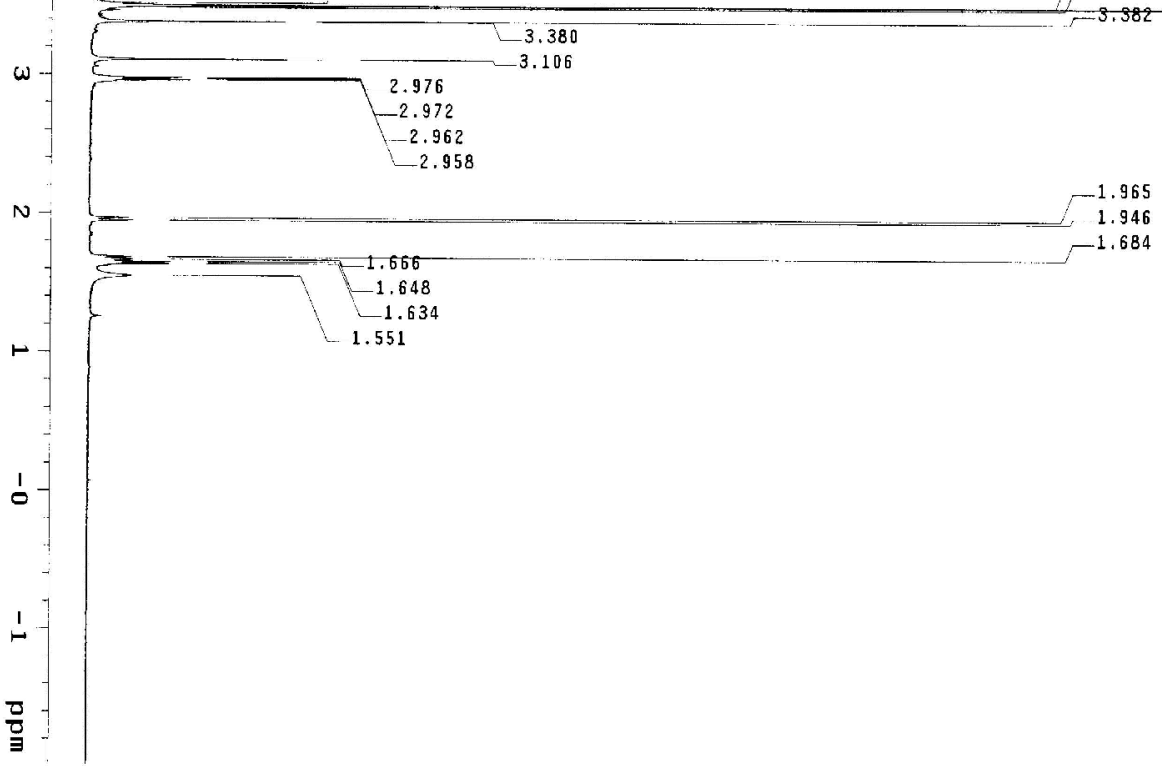




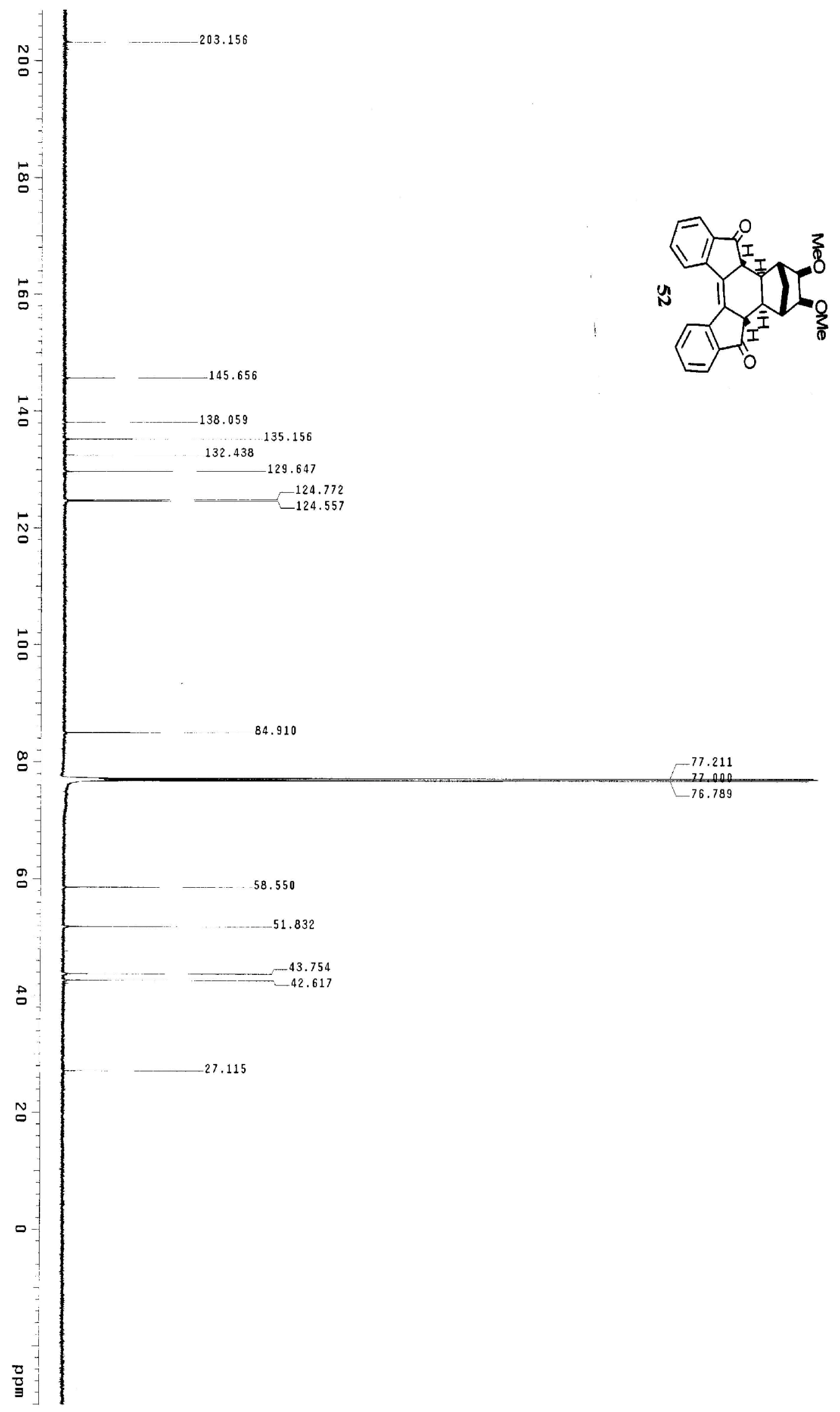




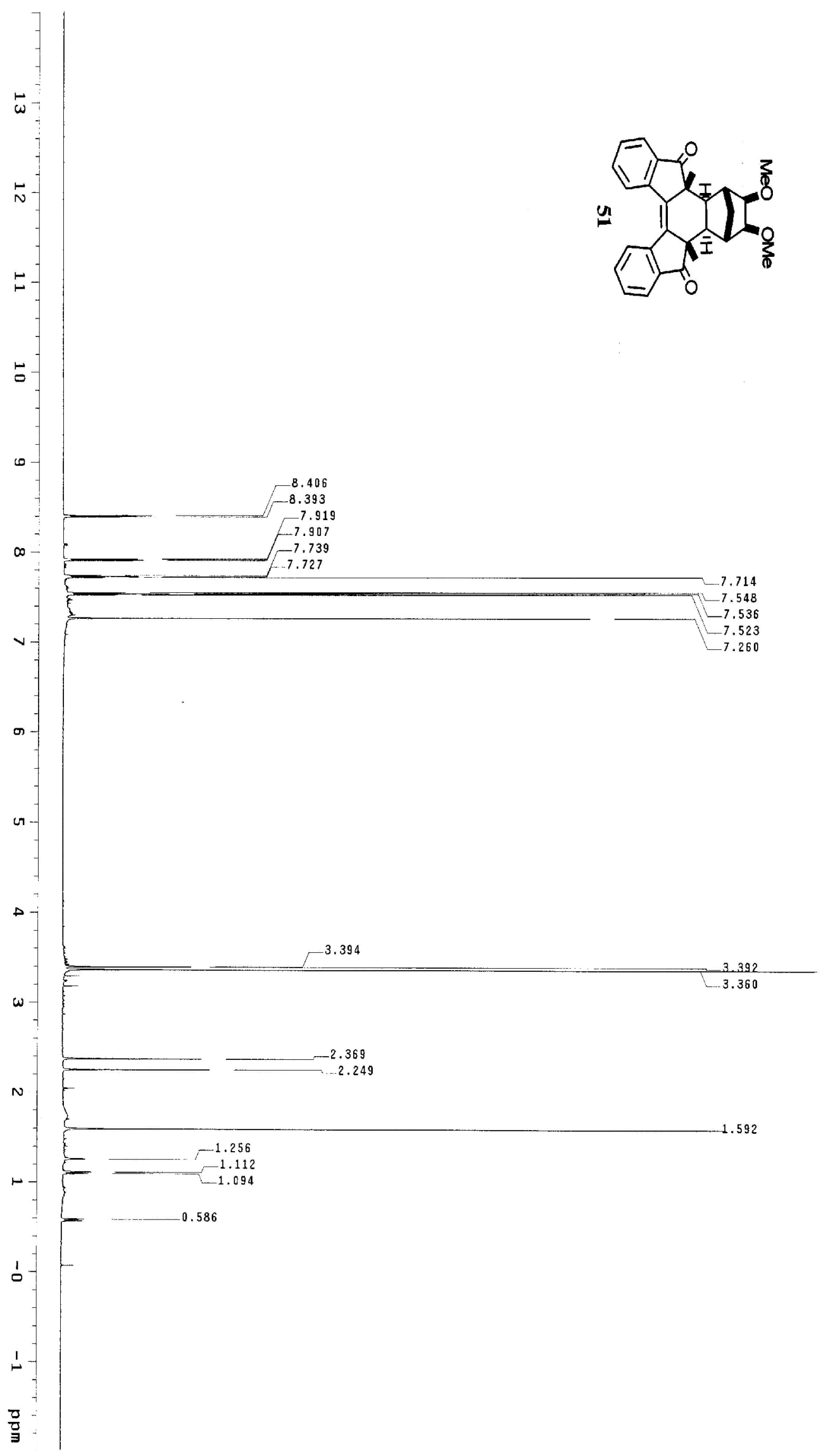




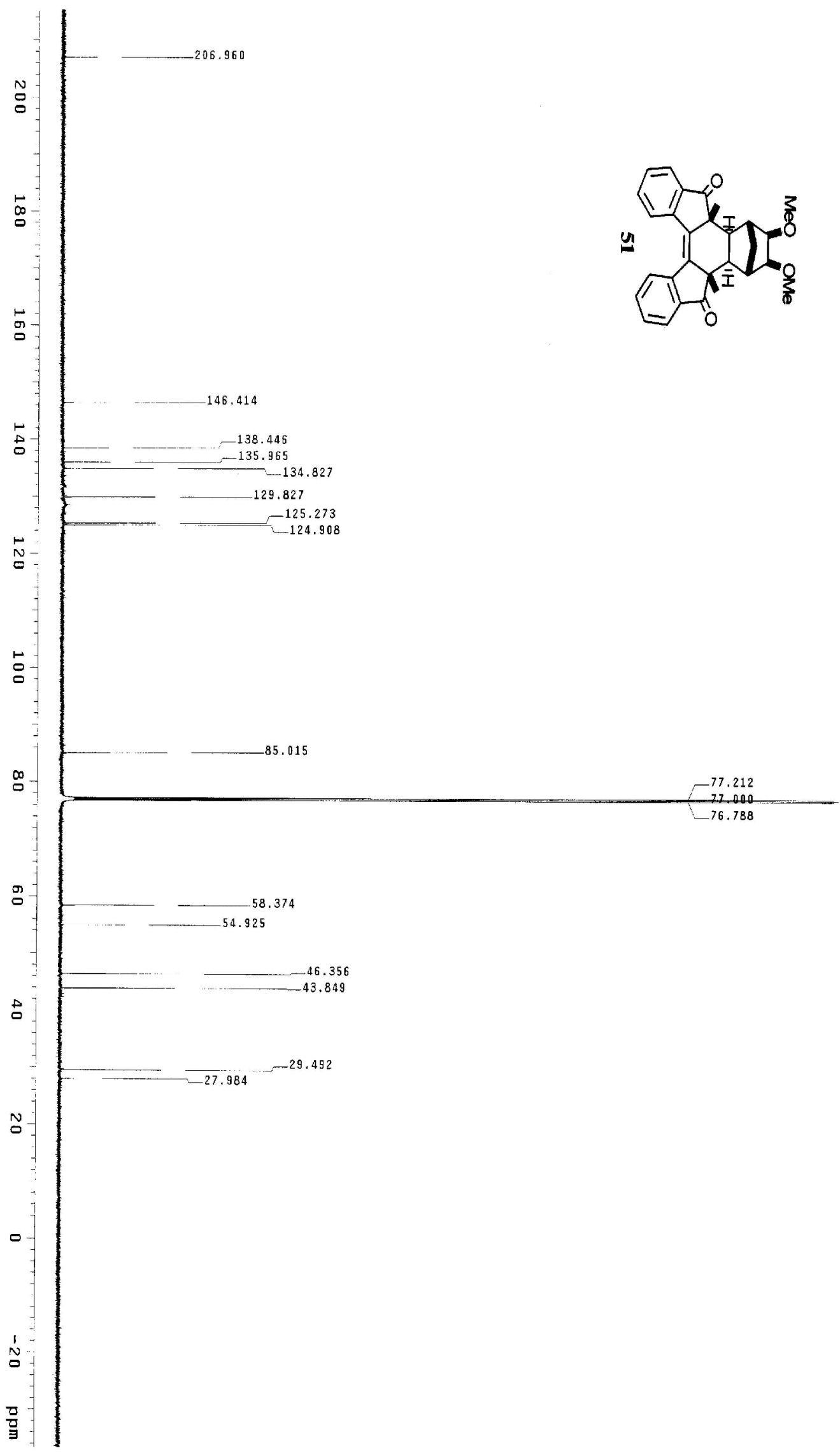




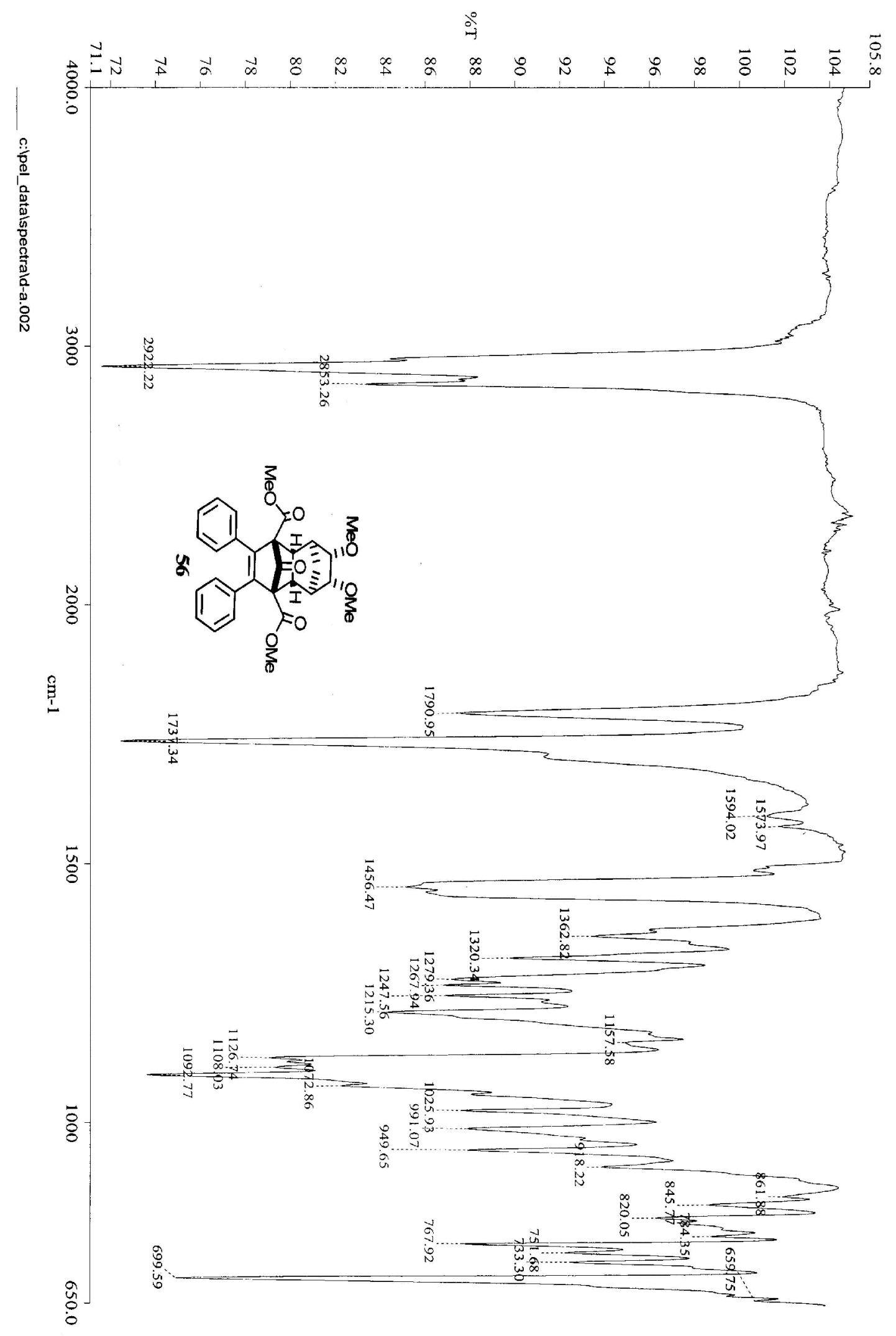




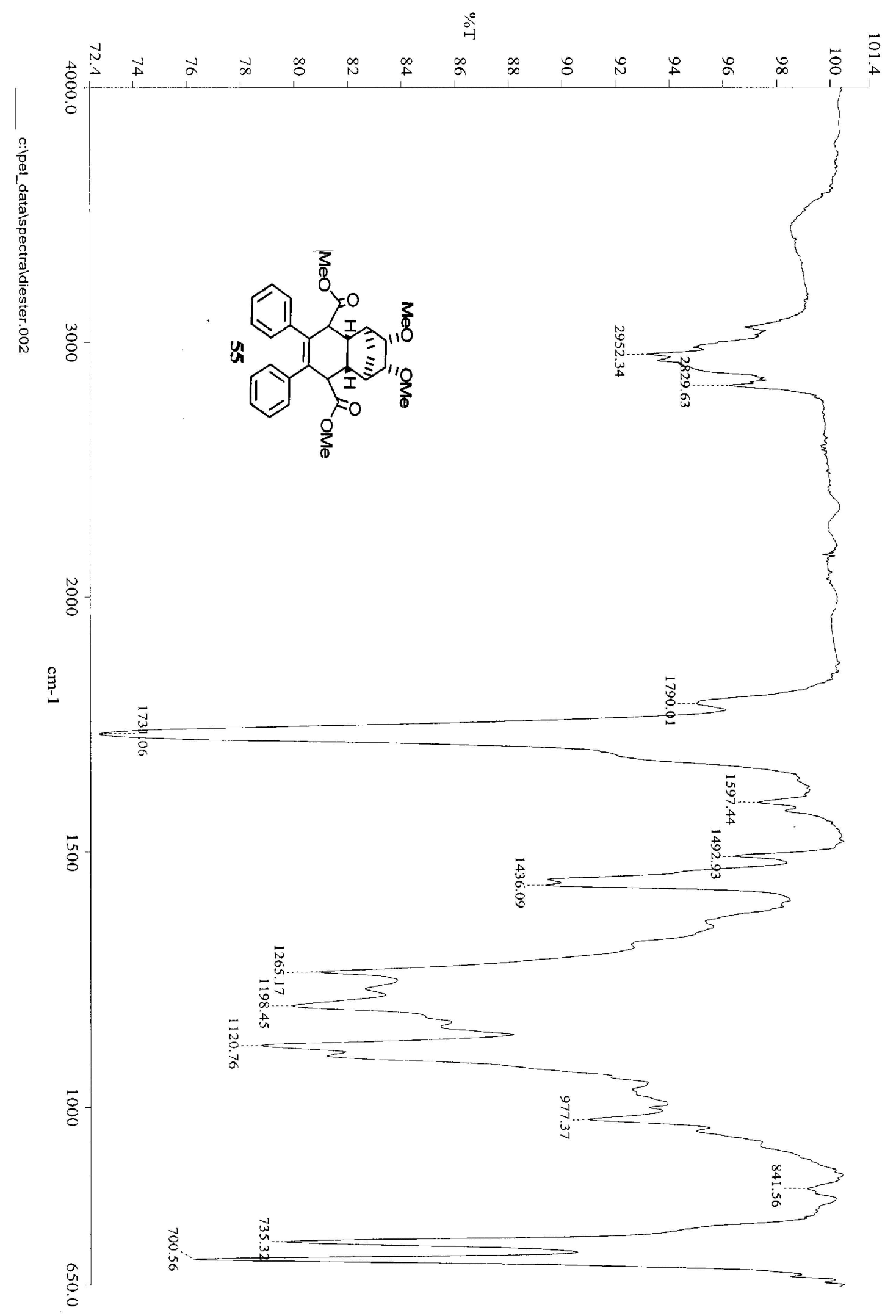




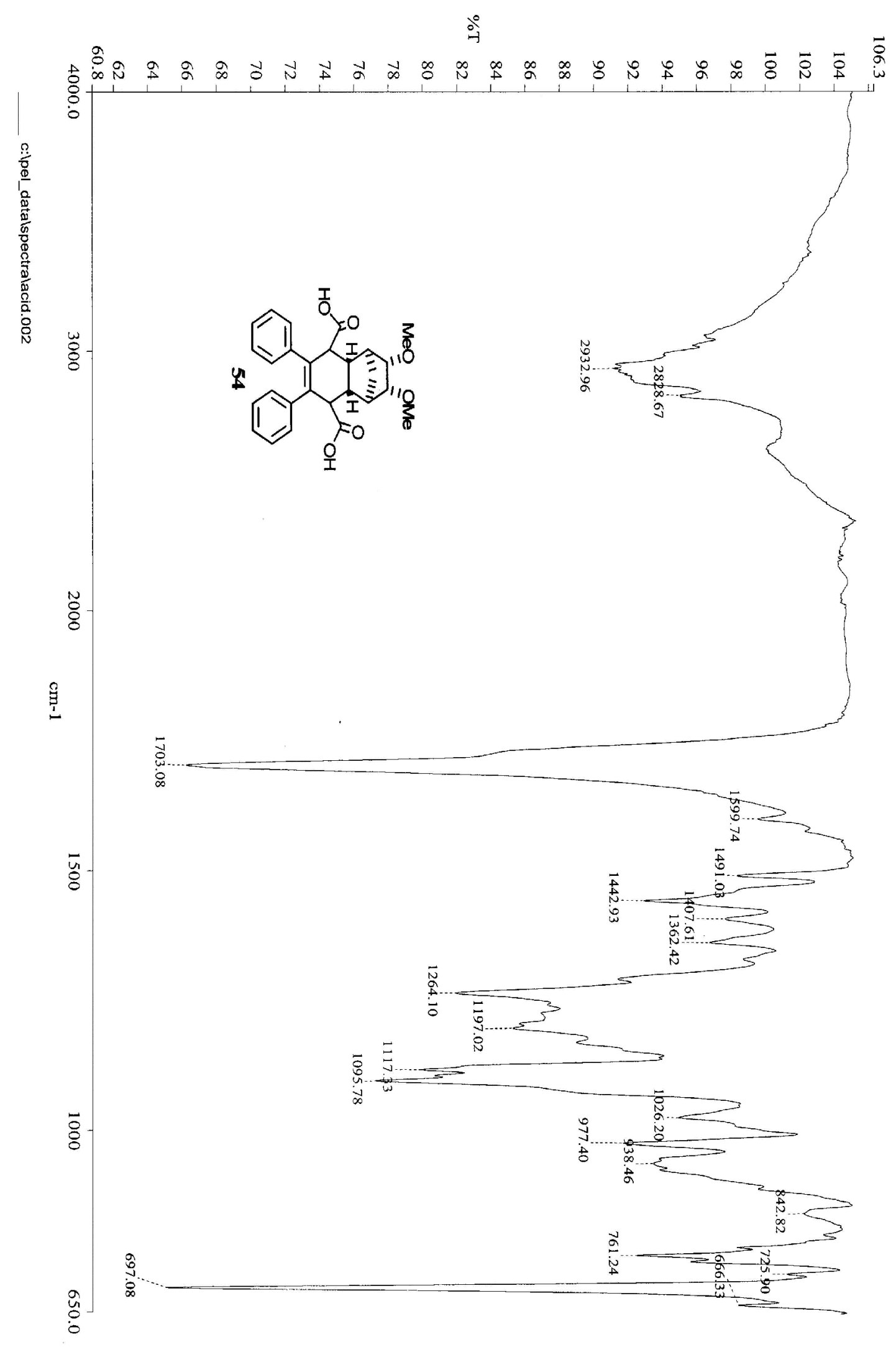




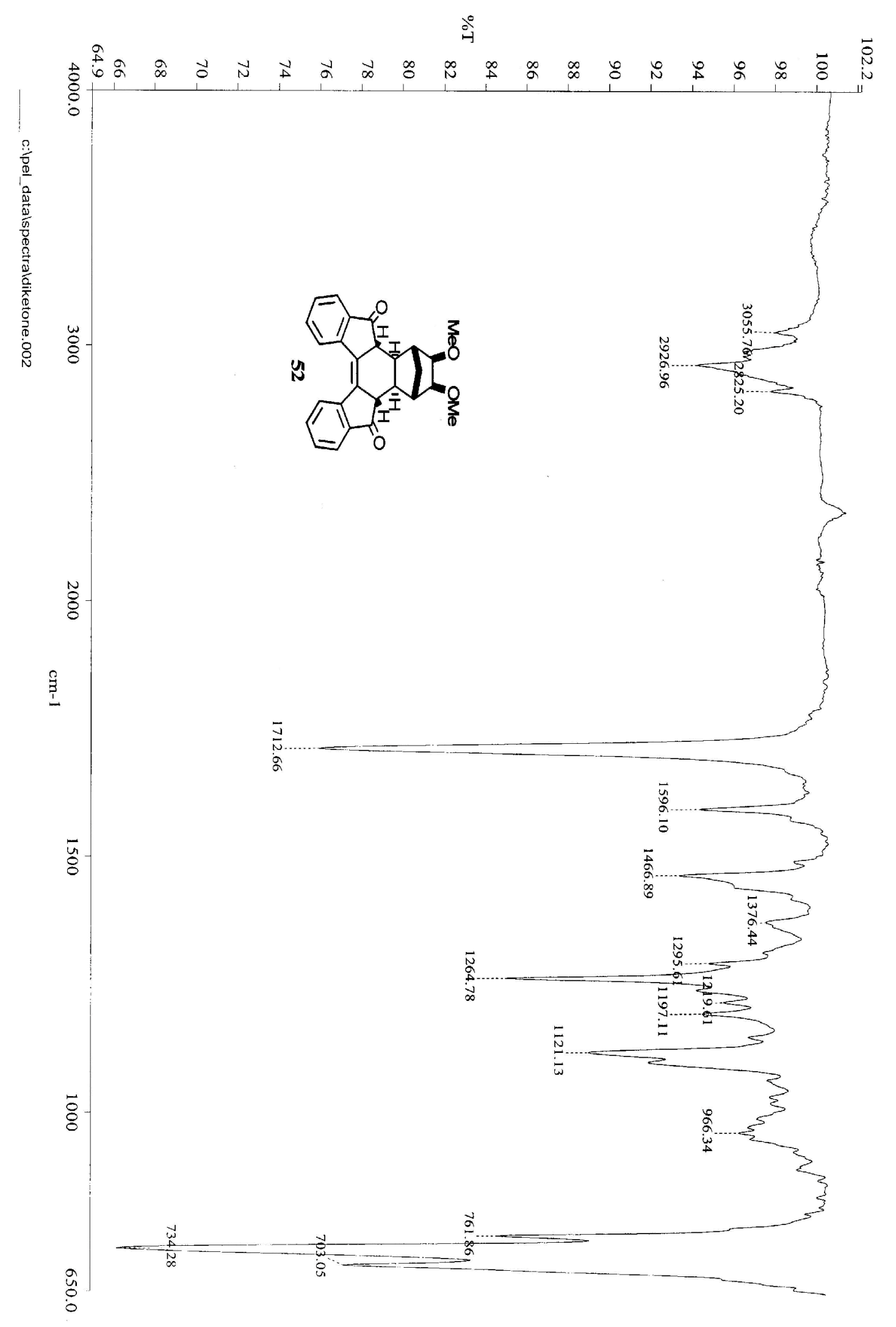




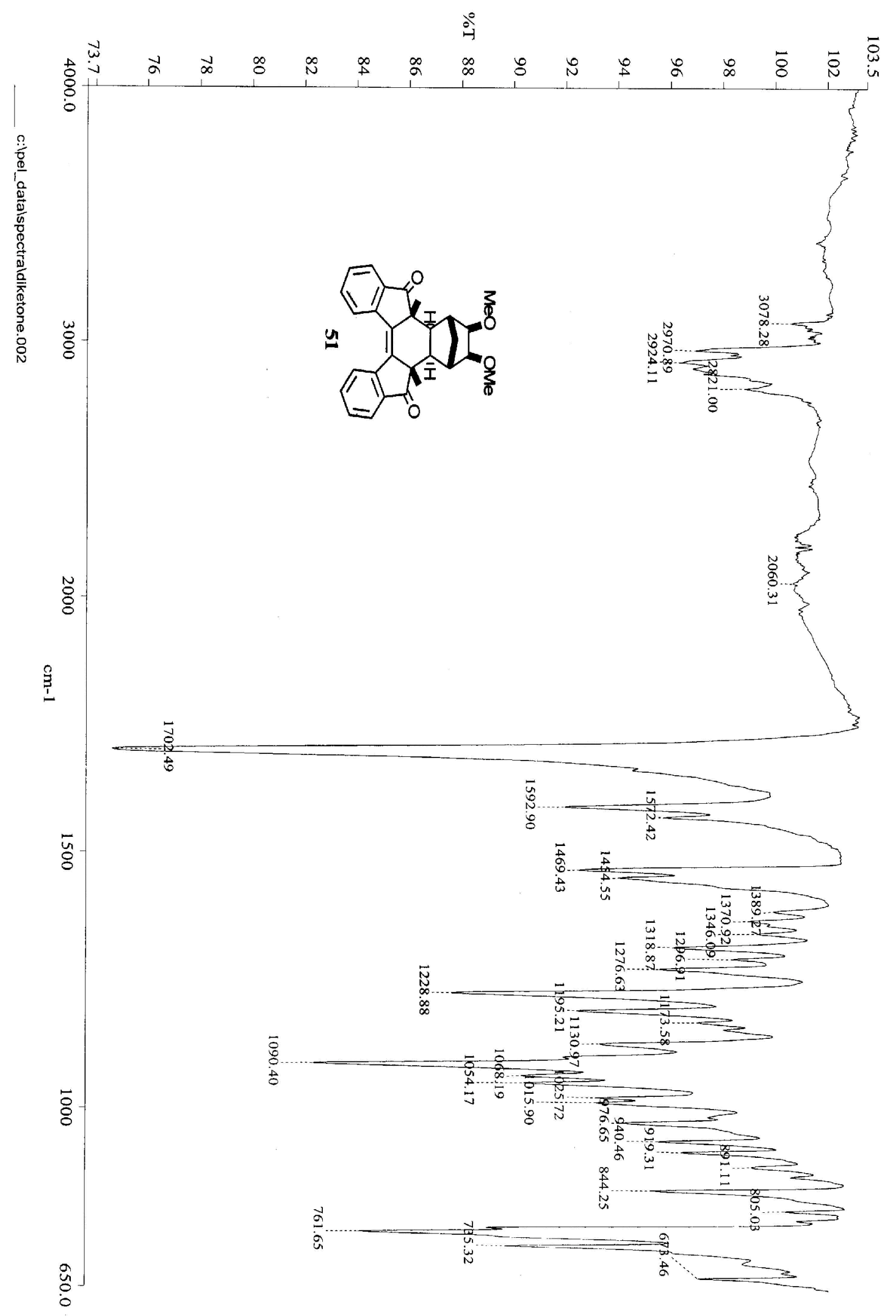

